\title{
Recent Advances in Ovarian Cancer: Therapeutic Strategies, Potential Biomarkers, and Technological Improvements
}

\author{
Salima Akter 1,2,3,+, Md. Ataur Rahman 4,5,6,+, Mohammad Nazmul Hasan ${ }^{7}$, Hajara Akhter ${ }^{8}$, Priya Noor ${ }^{3}$, \\ Rokibul Islam 9,10, Yoonhwa Shin 1,2,11, MD. Hasanur Rahman ${ }^{12}$ (D) Md. Shamim Gazi ${ }^{13}$, Md Nazmul Huda ${ }^{14}$, \\ Nguyen Minh Nam ${ }^{15}{ }^{(D}$, Jinwook Chung ${ }^{11}$, Sunhee Han ${ }^{1,2,11}$, Bonglee Kim ${ }^{4,5} \mathbb{D}$, Insug Kang ${ }^{1,2,11} \mathbb{D}$, \\ Joohun Ha ${ }^{1,2,11}$, Wonchae Choe ${ }^{1,2,11}$ (D), Tae Gyu Choi ${ }^{1,2, *}$ and Sung Soo Kim 1,2,11,*
}

\section{check for}

updates

Citation: Akter, S.; Rahman, M.A.;

Hasan, M.N.; Akhter, H.; Noor, P.;

Islam, R.; Shin, Y.; Rahman, M.H.;

Gazi, M.S.; Huda, M.N.; et al. Recent

Advances in Ovarian Cancer:

Therapeutic Strategies, Potential

Biomarkers, and Technological

Improvements. Cells 2022, 11, 650 .

https://doi.org/10.3390/

cells 11040650

Academic Editor: Frank Schnütgen

Received: 11 December 2021

Accepted: 10 February 2022

Published: 13 February 2022

Publisher's Note: MDPI stays neutral with regard to jurisdictional claims in published maps and institutional affiliations.

Copyright: (C) 2022 by the authors. Licensee MDPI, Basel, Switzerland. This article is an open access article distributed under the terms and conditions of the Creative Commons Attribution (CC BY) license (https:// creativecommons.org/licenses/by/ $4.0 /)$.
1 Department of Biochemistry and Molecular Biology, School of Medicine, Kyung Hee University, Seoul 02447, Korea; salima_2015@buhs.ac.bd (S.A.); jac03032@khu.ac.kr (Y.S.); sunheehan@khu.ac.kr (S.H.); iskang@khu.ac.kr (I.K.); hajh@khu.ac.kr (J.H.); wchoe@khu.ac.kr (W.C.)

2 Biomedical Science Institute, Kyung Hee University, Seoul 02447, Korea

3 Department of Medical Biotechnology, Bangladesh University of Health Sciences, Dhaka 1216, Bangladesh; priyabge1509@gmail.com

4 Department of Pathology, College of Korean Medicine, Kyung Hee University, Seoul 02447, Korea; rahman23@khu.ac.kr (M.A.R.); bongleekim@khu.ac.kr (B.K.)

5 Korean Medicine-Based Drug Repositioning Cancer Research Center, College of Korean Medicine, Kyung Hee University, Seoul 02447, Korea

6 Global Biotechnology \& Biomedical Research Network (GBBRN), Department of Biotechnology and Genetic Engineering, Faculty of Biological Sciences, Islamic University, Kushtia 7003, Bangladesh

7 Pristine Pharmaceuticals, Patuakhali 8600, Bangladesh; nobinbge@gmail.com

8 Biomedical and Toxicological Research Institute, Bangladesh Council of Scientific and Industrial Research (BCSIR), Dhaka 1205, Bangladesh; hajara@bcsir.gov.bd

9 Department of Biotechnology and Genetic Engineering, Faculty of Biological Sciences, Islamic University, Kushtia 7003, Bangladesh; mrislam@btge.iu.ac.bd

10 Department of Biochemistry, College of Medicine, Hallym University, Chuncheon 24252, Korea

11 Department of Biomedical Science, Graduate School, Kyung Hee University, Seoul 02447, Korea; cck608@khu.ac.kr

12 Department of Biotechnology and Genetic Engineering, Bangabandhu Sheikh Mujibur Rahman Science and Technology University, Gopalganj 8100, Bangladesh; hasanurrahman.bge@gmail.com

13 Biotechnology and Genetic Engineering Discipline, Khulna University, Khulna 9208, Bangladesh; shamimgazibge@ku.ac.bd

14 Department of Biochemistry and Molecular Biology, UAMS Winthrop P. Rockefeller Cancer Institute, University of Arkansas for Medical Sciences UAMS, Little Rock, AR 72205, USA; mnhuda@uams.edu

15 Research Center for Genetics and Reproductive Health, School of Medicine, Vietnam National University Ho Chi Minh City, Linh Trung Ward, Thu Duc District, Ho Chi Minh City 71308, Vietnam; nmnam@medvnu.edu.vn

* Correspondence: chtag@khu.ac.kr (T.G.C.); sgskim@khu.ac.kr (S.S.K.); Tel.: +82-2-961-0287 (T.G.C.); $+82-2-961-0524$ (S.S.K.)

+ These authors contributed equally to this work.

Abstract: Aggressive and recurrent gynecological cancers are associated with worse prognosis and a lack of effective therapeutic response. Ovarian cancer (OC) patients are often diagnosed in advanced stages, when drug resistance, angiogenesis, relapse, and metastasis impact survival outcomes. Currently, surgical debulking, radiotherapy, and/or chemotherapy remain the mainstream treatment modalities; however, patients suffer unwanted side effects and drug resistance in the absence of targeted therapies. Hence, it is urgent to decipher the complex disease biology and identify potential biomarkers, which could greatly contribute to making an early diagnosis or predicting the response to specific therapies. This review aims to critically discuss the current therapeutic strategies for OC, novel drug-delivery systems, and potential biomarkers in the context of genetics and molecular research. It emphasizes how the understanding of disease biology is related to the advancement of technology, enabling the exploration of novel biomarkers that may be able to provide more accurate diagnosis and prognosis, which would effectively translate into targeted therapies, ultimately improving patients' overall survival and quality of life. 
Keywords: ovarian cancer; angiogenesis; technology advances; molecular insight; therapeutic strategies and targets

\section{Introduction}

Ovarian cancer $(\mathrm{OC})$ is the presence of abnormal cells that initially grow in the ovary and then reproduce out of control, which can form a tumor malignancy when they spread into the surrounding tissues [1,2]. Ovaries are made up of three types of cells, and each cell can develop into diverse types of tumors. Approximately $90 \%$ of ovarian cancers have been found to be of epithelial origin [3], including high-grade and low-grade serous carcinoma and clear cell, endometrioid, and mucinous carcinoma, while $7 \%$ of OCs have been shown to be stromal types, and OCs from germ cell tumors are found only rarely [1]. It has been found that there are frequently warning symptoms and signs for OC; however, the earliest symptoms are unclear and hard to detect due to shared gastrointestinal, genitourinary, and gynecological conditions [4]. A number of barriers to the treatment of the disease exist $[5,6]$. Despite the early high rates of response to initial chemotherapy and radical surgery for about $70 \%$ of patients with relapses and intermediate progression-free 12 - to 18-month survival, long-term survival remains poorly understood, with a high risk of reappearance [7]. Additionally, chemotherapeutic treatments for OC have an undesirable impact on quality of life because of their severe side effects, including fatigue, arthralgia, and neurotoxicity $[8,9]$. Therefore, understanding the biology of heterogeneous OCs is vital for exploring the disease's mechanisms more accurately [4]. Potential therapeutic targets for the management of $\mathrm{OC}$ are being explored, such as intrinsic signaling pathways, angiogenesis, hormone receptors, and immunologic factors.

Bevacizumab, the most-studied anti-VEGF-targeted therapy inhibiting angiogenesis in the tumor microenvironment, holds great promise for OC treatment, but redundant angiogenic pathways make the drug show only modest efficacy $[5,6,10,11]$. Meanwhile, there has been a surge in clinical trials with several drug candidates that precisely target signal enzymes, which may induce apoptosis and autophagy, targeting the inhibition of angiogenesis in site-specific OC cells [12-15]. However, to understand the disease's pathophysiology, it is essential to thoroughly investigate the regulatory mechanisms in terms of the different molecular layers and time intervals, which may clearly demonstrate the disease dynamics [16,17]. Indeed, the use of molecular profiling for patients with OC may provide effective strategies for treating the disease. Using multi-omics data, it may be possible to gain a comprehensive understanding of the tumor's biology, which could make it feasible to discover prognostic biomarkers or predictors to facilitate the early diagnosis and prognostic prediction of aggressive and advanced $O C$, which could ultimately help in treatment decisions $[4,18,19]$.

Drug delivery or co-delivery systems represent another crucial approach for OC treatment. Single targeted drugs or multiple targeted agents have been engineered for drugdelivery systems that realize drug release more effectively and reduce toxicity. The present study attempted to evaluate the recent understanding of ovarian cancer associated with signaling mechanisms, targeted therapeutic strategies, and potential drug delivery systems. In particular, the interplay between technological advancement and the management of this heterogeneous disease from diverse perspectives is highlighted.

\section{Targeting Numerous Signaling Pathways of Ovarian Cancer}

Surgery and chemoradiotherapy are the most frequently used treatment options for ovarian cancer (OC) [20]. However, severe side effects have been associated with chemoand radiotherapy (RT), while the only minor therapeutic benefit from RT eventually leads to succumbing to the disease and poor survival outcomes [21]. Hence, targeting specific signaling pathways would be a promising molecular approach to ovarian cancer therapy in terms of inhibiting tumor growth, cell invasion or migration, and metastasis. It was 
found that seven major signaling pathways are commonly upregulated in ovarian cancers (>50\%): the PI3K/AKT/mTOR, Jak/STAT, Src, lysophosphatidic acid (LPA), NF-KB, PKCı, and Mullerian inhibitory substance receptor signaling pathways have shown high levels of mutation and/or hyperactivation strongly associated with aggressive phenotypes and advanced disease stages, leading to poor prognosis for the disease [4,22]. In this section, we briefly describe some signaling pathways related to tumorigenesis and metastasis that may be potentially targetable and provide information regarding novel inhibitors currently in clinical trials.

\subsection{PI3K/AKT/mTOR Pathway}

Phosphoinositide 3-kinase (PI3K)/AKT/mammalian target of rapamycin (mTOR) signaling is one of the most important pathways controlling cell growth, proliferation, differentiation, and survival [23]. The pathway is regulated by multiple ligands, such as growth factors (IGF, EGF, TGF, and others), receptor tyrosine kinases (IGF-1R, FGFR, HER2, EGFR, and PDGFR), and various membrane receptors [24-26]. Indeed, mutations in several components of the pathway are very common in most human cancers, including subtypes of OC [27]. It has been shown that the aberrant expression and activation of AKT (pAKT) is strongly correlated with poor progression-free and overall survival in epithelial OC [28]. Whole-genome sequencing analysis revealed that gene breakage frequently inactivates the tumor-suppressive ability of RB1, PTEN, NF1, and RAD51B in high-grade serous ovarian cancer, resulting in acquired chemoresistance [29]. In particular, OC stemness (CSC), the key regulatory factor of aggressive cancer, is directly modulated by PI3K/PTEN/AKT signaling, causing CSC enrichment, CSC phenotyping maintenance, and multidrug resistance (MDR) [30,31], which leads to abnormal cell proliferation and cancer metastasis through epithelial-mesenchymal transition [32]. The well-studied mTOR inhibitors for OC include temsirolimus, ridaforolimus, and everolimus, for which phase II clinical trials have been completed [13]. In recent in vitro and in vivo studies, SPR965, a dual inhibitor of PI3K and mTORC1/2, has been proven to have antitumorigenic activity in diverse solid tumors, including serous ovarian cancer. However, further clinical trials are needed before it can be recommended as a novel targeted therapeutic agent [33]. Afuresertib, an Akt inhibitor, showed a satisfactory safety profile in platinum-resistant OC in a phase I study, and the drug NCT04374630 is under investigation for use in combined therapy with paclitaxel in platinum-resistant OC in a phase II trial (Figure 1).

\subsection{JAK/STAT Signaling Pathway}

The JAK/STAT pathway is a crucial signaling pathway that is abnormally activated in OC, and its constitutive activation is strongly related to tumor progression and poor prognosis for the disease [34]. Hyperstimulation of this pathway has also been found in other cancers, including breast, gastric, lung, prostate, and hematopoietic malignancies [35-37]. JAK/STAT pathway-mediated tumor progression is mainly due to the expression of a variety of proteins and cytokines involved in cellular proliferation, stemness and self-renewal, survival, and evasion of antitumor immunity [37,38]. Studies have found that more than 50 cytokines and growth factors are responsible for this pathway initiating hematopoiesis, inflammation, and immune suppression in the tumor microenvironment [38]. STAT is a key driver of immunosuppression through triggering the production of immune checkpoint genes (e.g., PD1, PD-L1, PD-L2, and CTLA-4) [39], promoting radio- and/or chemoresistance and the failure of targeted immunotherapies [22]. 


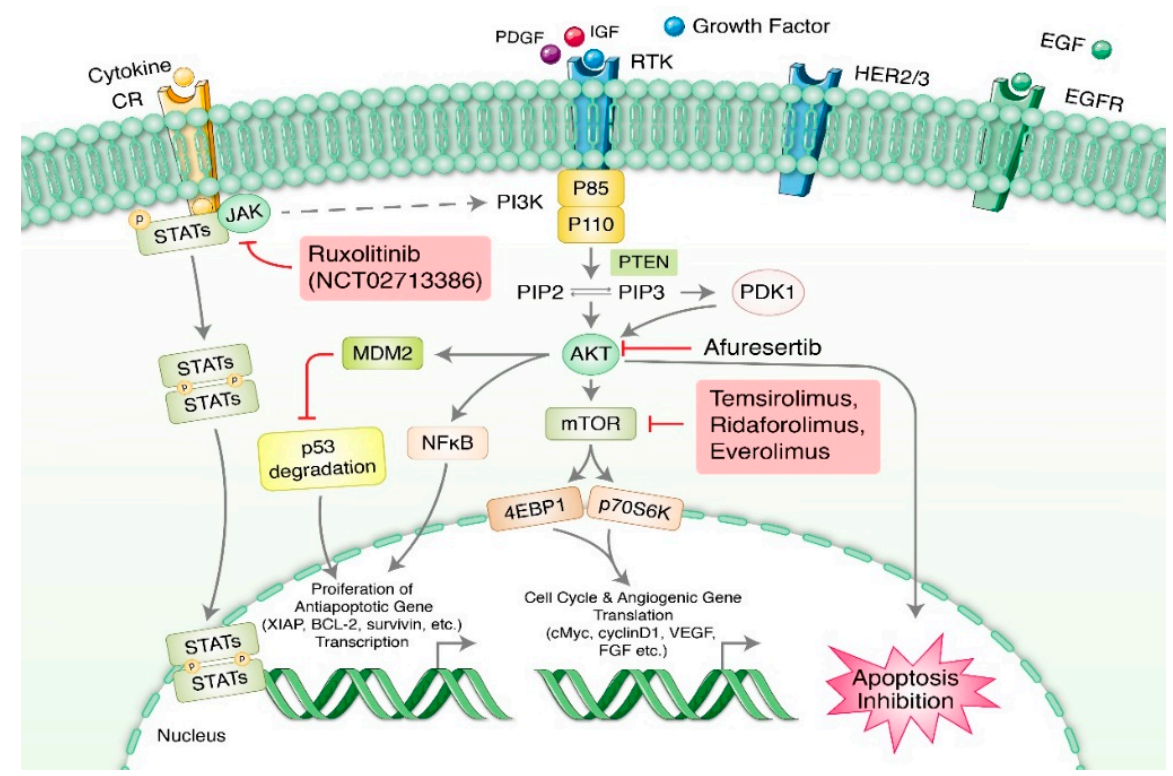

Figure 1. PI3K/Akt/mTOR signaling pathway. This pathway is upregulated in ovarian cancer by either (i) receptors of upstream growth factors and ligand stimulation, (ii) indirect activation via cross-talk with JAK/STAT signaling, or (iii) intrinsically via activation of amplified/mutated PI3K or amplification of Akt isoform, or deletion/inactivation in tumor-suppressor protein PTEN. Afuresertib, an Akt inhibitor, is safely used in platinum-resistant ovarian cancer. Most frequently studied mTOR inhibitors in completed OC phase II clinical trials are temsirolimus, ridaforolimus, and everolimus. Ruxolitinib, a JAK inhibitor, is already FDA approved for treatment of polycythemia vera.

JAK inhibitors have been found to be essential in the treatment of cancer in recent years. Many JAK inhibitors have demonstrated efficacy in clinical settings, and a number of inhibitors/analogs are currently being studied. Ruxolitinib is a JAK inhibitor already approved by the FDA for the treatment of polycythemia vera; in preclinical studies, it was found that the drug reduced cell viability in OC [40]. NCT02713386 is being investigated for use in combination therapy with paclitaxel and carboplatin in stage III-IV OC in a completed phase I/II trial [13]. AZD1480, a small-molecule JAK inhibitor, was demonstrated to suppress OC growth in a mouse model via cascade inhibitory effects on STAT3 phosphorylation, DNA binding, migration, and the adhesion of cultured ovarian cancer cells [41]. AH057 may effectively block the pathway by inhibiting the function of JAK1/2 kinase, resulting in increased cell cycle arrest and apoptosis, and impaired tumor progression and invasion, as shown in vitro and in vivo [42]. In CSC, CYT387 administration with paclitaxel was shown to suppress JAK2/STAT3 activity and paclitaxel-induced Oct 4 and CD117 (CSC-like marker) expression in a mouse xenograft model, suggesting the development of CSC-targeted therapy [43]. Higher levels of aldehyde dehydrogenase (ALDH), a characteristic feature of endometrial cancer progenitor and stem cells, upregulates IL-6 and signal transducer CD126 and GP130 expression, while the blockade of the IL6 receptor dramatically suppresses downstream effector IL6/JAK1/STAT3 signaling, eventually reducing tumor cell growth [44]. Taking all the data together, the continuous activation of the JAK/STAT pathway is certainly implicated in many types of human malignancies, while the potential effect of JAK inhibitors on cancer development remains a source of concern [45]. Therefore, the safety and benefits of JAK inhibitors still need to be determined.

\subsection{Wnt/B-Catenin Pathway}

The interest in Wnt signaling began in 1982 and has steadily increased due to the extreme renewal, proliferation, and differentiation properties of CSCs, thus showing an important role for them in tumorigenesis and therapy resistance in many malignancies [46]. Wnt signaling exemplifies several pathways, such as Notch-Delta, Sonic-Hedgehog, Hippo, 
and transforming growth factor $\beta$ (TGF- $\beta$ )/bone morphogenetic protein (BMP), which are directly implicated in developmental and evolutionary processes [47], thereby facilitating its widespread activity. Wnt signaling seems to regulate tumorigenesis in ways that are both $\beta$-catenin-dependent (canonical, primarily for cell proliferation) and $\beta$-cateninindependent (noncanonical, controlling cell polarity and movement) [48]. Although Wnt signaling has been linked to the incidence and progression of ovarian cancer [49], its possible consequences in ovarian cancer are still being investigated.

Mutations in the components of the Wnt pathway are causal factors for multiple growth-associated pathologies in cancer [47]. A number of possible mechanisms are involved in Wnt pathway hyperactivation, including the upregulation of ligands and receptors, the downregulation of the $\mathrm{Wnt} /$ beta-catenin pathway inhibitors, and altered protein function, which in turn control the interaction between beta-catenin and E-cadherin or beta-catenin and TCF. These abnormalities have been noted in EOC, especially in the high-grade serous subtype [50]. Furthermore, the involvement of several noncoding RNAs (IncRNAs, miRNAs, and circRNAs) in regulating beta-catenin signaling in EOC has recently been demonstrated [51]. Wnt signals regulate the cell cycle at several points. In endometrial and mucinous subtypes of EOC, mutations have been observed in, for example, the CTNNB1, AXIN, and APC genes [50]. The crucial role of the Wnt pathway in OC development, progression, angiogenesis, metastasis, and chemoresistance is supported by its strong CSC (cancer stem cell) self-renewal, EMT (epithelial-mesenchymal transition), and invasion capabilities and tumor immunity suppression [52]. Apart from tumorigenesis, there is a direct impact of the Wnt signaling pathway on immune responses. Recently, several cancer-specific inhibitors of this signaling pathway have been identified, including WNT974, which increases antitumor immunity in ovarian cancer [53]. Thus, $\beta$-catenin may be a promising therapeutic target in chemoresistance subtypes of EOC with CSCs.

\subsection{Apoptotic Signaling Pathway'}

Apoptosis is a characteristic and orderly energy-mediated biochemical cellular suicide process that maintains homeostatic equilibrium between the proportion of cell death and cell formation in multicellular creatures [54,55]. It is well evidenced that apoptosis induction acts as a hallmark barricade to cancer development [56-58]. The B-cell lymphoma-2 (BCL2) family and inhibitors of apoptotic proteins (IAPs) are the predominant components of intrinsic apoptotic pathway induction through caspase activation, which regulates mitochondrial membrane permeabilization through apoptotic switching [59]. Alternatively, the extrinsic apoptotic pathway triggers tumor necrosis factor (TNF)-related apoptosisinducing ligand (TRAIL) to the cell surface receptor signaling cascade [60]. Several studies imply that both signaling cascades may be activated simultaneously to induce apoptosis in human ovarian cancer $[61,62]$. In particular, it has been proposed that apoptosis induction is broadly mediated by caspase- 3 pathway activation, which has been established by increased sensitivity to paclitaxel using adenoviral type 5 E1A in human HER-2/neuoverexpressing ovarian cancer SKOV3.ip1 cells. In this pathway, caspase-3 executes the proteolytic cleavage of cellular proteins to progress apoptosis [63].

Enzastaurin (LY317615.HCl), a radiosensitizing, ATP-competitive, discriminating protein kinase C beta (PKC-beta) inhibitor, is an alternative drug that inhibits tumor cell growth through the upregulation of caspase-3 and caspase-9's proapoptotic activity [62]. Among different analyses, a combination treatment with enzastaurin and pemetrexed was shown to cause apoptosis induction in chemotherapy-resistant ovarian cancer HEY cells, controlling phosphorylated GSK3 $\beta$ and inhibiting mitogen-activated protein kinase ERK1/2 (extracellular signal-regulated kinase)-mediated cell growth [64]. In addition, a current study reveals that metformin induces an apoptotic pathway in OVCAR-3 and OVCAR-4 cell lines in an AMP-activated protein kinase (AMPK)-independent manner, resulting in S- and G2/M-phase cell cycle arrest. Metformin may also induce apoptosis by downregulating Bcl2 and Bcl-xL protein expression and caspase 3/7 activation, and augmenting Bax and Bad expression in human OVCAR-3 and OVCAR-4 cell lines. Furthermore, metformin-induced 
apoptosis is augmented by the addition of cisplatin without modulating the appearance of Bcl-2 proteins in the OVCAR-3 cell line, although BcL-2 was expressed in the OVCAR-4 cell line [65].

Resveratrol, a small polyphenol compound, increases apoptosis induction by activating it in an AMPK-dependent manner, and activates caspase 3, which leads to the inhibited expression and activation of mTOR, a downstream signaling target of AMPK, in ovarian cancer cells [66]. Moreover, TRAIL has been reported as an alternative therapeutic target for ovarian cancer management, although the targeted restriction of tyrosine kinase family proteins (PYK2 and FAK) and BCL-XL works synergistically and increases apoptosis in human ovarian carcinoma cell lines. The study revealed that the mitochondrial division inhibitor-1 (mdivi-1) increases the sensitivity of ovarian cancer cells to cell surface ligands such as FAS, TRAIL, and TNF-alpha [67]. A recent study demonstrated that berberine (BBR), a potent anticancer drug, combined with cisplatin (DDP) enhanced apoptosis by inhibiting PCNA and Ki67 expression and upregulating caspase-3, caspase-8, RIPK3, and MLKL expression and activation in the OVCAR-3 and POCCL ovarian cancer cell lines [68] (Figure 2).

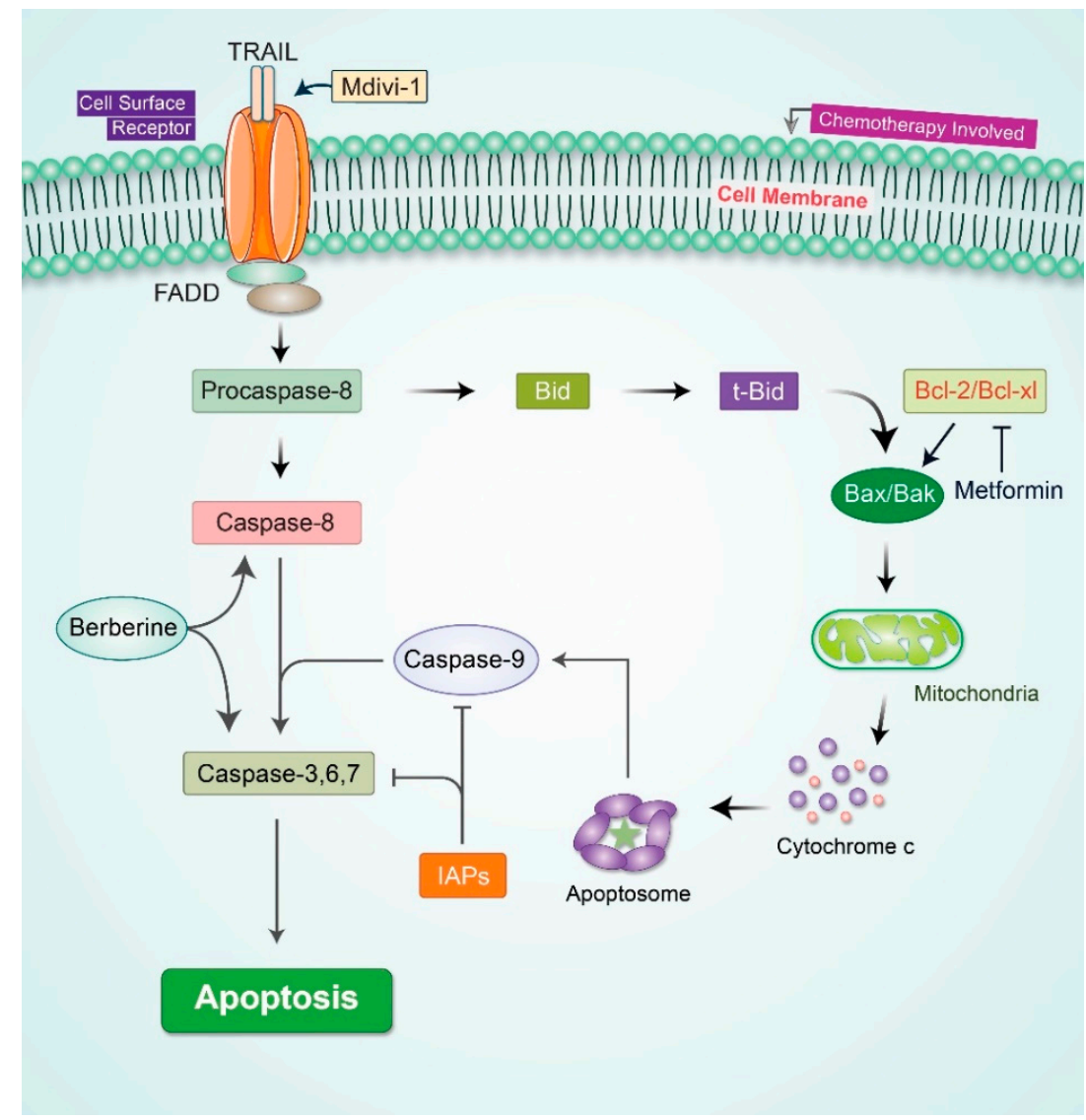

Figure 2. Apoptosis signaling in cancer cells. Metformin-induced apoptotic pathway in ovarian cancer cell lines stimulates AMP-activated protein kinase (AMPK)-independent apoptotic pathway. Berberine activates caspase- 8 and caspase-3-mediated apoptotic pathway. Mdivi-1 stimulates TRAILinduced extrinsic pathway.

\section{Autophagy Modulation in Ovarian Cancer Management}

Autophagy is a self-digestion process that assists in maintaining cellular homeostasis by recycling unwanted or damaged toxic cellular organelles in cells $[69,70]$. The modulation of autophagy has been implicated in regulating several cancers [71,72]. It has been suggested that autophagy is an important function in ovarian cancer via the expression of autophagy-related proteins, which comprise the microtubule-associated proteins light 
chain (LC-3), beclin-1, and p53 [12]. Beclin-1 is a tumor-suppressor protein that has an essential checkpoint role in apoptosis and autophagy in tumor cells [73]. Beclin-1 expression has been found to be downregulated in ovarian cancers compared to benign lesions [74], suggesting the predictive potential of the beclin-1 protein in OC. Furthermore, the cytoplasmic localization of p53 mutants has been shown to prevent autophagy [75]. Additionally, $\mathrm{Bcl}-2$ expression was found to prevent autophagy by interacting with beclin-1, and the overexpression of mutant p53 protein may impact autophagy in ovarian cancer cells [76]. Later, the p53-mediated regulation of autophagy was validated in a clinical study [77].

Aplasia Ras homolog member I (ARH1), another protein, has been found to be upregulated in autophagy via the mTOR-dependent pathway, which activates autophagy-mediated dormancy [78]. In approximately $70 \%$ of cases of ovarian cancer, PI3K/AKT/mTOR pathways have been shown to be constitutively triggered by autophagy, which has been considered to be a therapeutic target of ovarian cancer [79]. It was reported that a specific PI3K inhibitor, LY294002, given as treatment for ovarian cancer in an established mouse model, prevented ovarian cancer cell proliferation [80]. Additionally, the cellular cytotoxic effects of novel chemotherapeutic agents were shown to be efficiently improved through cotreatment with a noncompetitive AKT inhibitor, TAS-117, in in vivo models of ovarian cancer [81]. Sirtuin 3 (Sirt3), a member of the sirtuin protein family, performs an essential function in maintaining ovarian cancer intracellular homeostasis in a close mutual monitoring relationship, as well as autophagy. Studies showed that metformin-mediated Sirt3 overexpression encouraged mitochondrial dysfunction and apoptosis via the activation of AMPK in ovarian cancer cells [82]. In addition, Sirt3 may similarly control autophagy through glutathione S-transferase and JNK-mediated autophagy pathways, and Sirt3 knockdown was shown to relieve S1-induced apoptosis in ovarian cancer cells [83] (Figure 3).

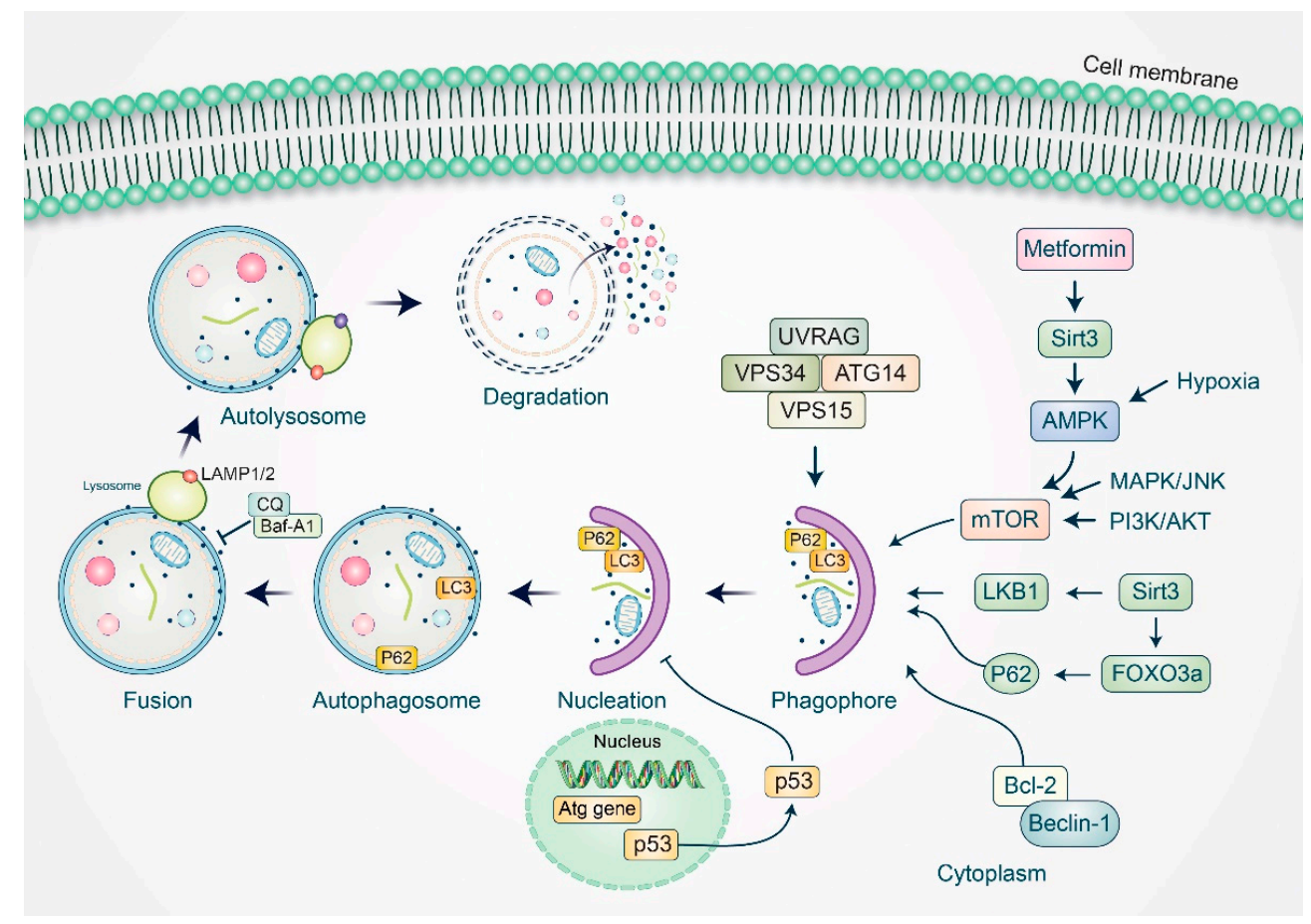

Figure 3. Modulation of autophagy signaling in relation to Sirt3 and autophagy in ovarian cancer. Metformin-mediated Sirt3 overexpression triggers AMPK, which increases activation of LC3. Sirt3 is also involved in autophagy regulation through MAPK/JNK/mTOR autophagy pathway. Several autophagy-related genes, such as beclin-1, p62, LKB1, and VPS34 complex, stimulate autophagy initiation. Sirt3 also activates FOXO3a, which subsequently activates p62 and autophagy. Transcription factor p53 activates and promotes synthesis of autophagy proteins, and high cytoplasmic levels of p53 may result in inhibition of autophagosome formation. 


\section{Novel Treatment Strategies for Epithelial Ovarian Cancer (EOC)}

The identification of novel therapeutic targets has been linked to better prognosis in ovarian cancer (OC). Advancements in the understanding of ovarian cancer biology have resulted in the development of numerous molecular targets, including growth factor receptors, cell cycle regulators, signal transduction pathways, and angiogenic mechanisms. The molecularly targeted agents possess higher selectivity and lower toxicity than conventional chemotherapy [84]. Major therapeutic targets used alone or in combination with cytotoxic drugs for OC treatment and new drugs in clinical trials are reviewed in this section.

\subsection{Therapeutic Approaches and Targets in Ovarian Cancer}

Given the enormous number of potential epithelial ovarian cancer treatments, it is useful to review the pathobiology of the disease to find relevant targets. The drug targets telomerase, HER2, AKT EGF-R, VEGF-R, and p53 are currently being studied in clinical trials $[13,85]$. Some specific targets are found only in OC, while some found in a wide variety of cancers $[85,86]$ are briefly discussed.

\subsection{Angiogenesis and VEGF Signaling Pathway}

Angiogenesis is the process of forming new blood vessels, which enables nutrients and oxygen to enter the surrounding tissues, thus promoting tumor cell proliferation, invasion, and metastasis $[87,88]$. The growth of blood vessels or new capillaries starts with vasodilation, increased vascular permeability, stromal disintegration, and endothelial cell proliferation and migration $[89,90]$. Researchers have discovered that receptor tyrosine kinases (RTKs), VEGF and its receptor (VEGFR), and Flk-1/KDR RTK play key roles in pathological angiogenesis, particularly tumor neovascularization [91]. An immediate impact on tumor growth is observed (slowdown or stoppage) when the VEGF signaling pathway is blocked or inhibited [92]. This insight into the mechanism of angiogenesis led to the establishment of several treatment methods targeting the VEGF pathway.

Bevacizumab is an anti-VEGF antibody and the most studied VEGF-targeting therapy for ovarian cancer $[93,94]$. The best response of the drug has been found in recurrent ovarian cancer, and it can be administered alone or with chemotherapy [95-97]. Current ovarian cancer clinical trials with bevacizumab show promising results (PFS) in two major first-line studies, ICON7 [98] and GOG 218 [99]. Along with carboplatin/paclitaxel, the GOG study uses bevacizumab as part of a triplet to treat patients with minimal cytoreduction of ovarian cancer [100]. Other potential VEGF-targeting medicines, including soluble decoy VEGF receptors such as aflibercept (VEGF TRAP) [101] and VEGF kinase inhibitors such sunitinib (SU11248, Sutent, Pfizer), have shown significant treatment benefit in EOC patients [14].

\subsection{ErbB Family Kinases}

The EGF family of RTKs, also known as ErbB or HER receptors, has been widely investigated in pharmacological research targeting human cancer. Numerous hypotheses have been suggested for HER2-mediated cell transformation through multiple mechanisms, such as EGFR and ErbB-3 interaction, which exhibit tyrosine phosphorylation and the activation of a cytoplasmic signaling pathway, while ErbB1 and ErbB2 homodimers transform fibroblasts using differential signaling [102,103]. Trastuzumab (Herceptin), a targeted monoclonal antibody for ErbB2, is approved for treating ErbB2 1 breast cancer. According to the GOC study, trastuzumab had limited action in ovarian cancer [104]. A partial but longlasting response was observed when combination therapy with trastuzumab-pertuzumab was used in a young woman with high-grade serous ovarian cancer (FIGO stage IV) [15]. Furthermore, a number of EGF-R targeting agents are currently in clinical trials [105-107], while some agents have shown exciting antitumor performance in CRC-based xenograft models and cell lines, such as cabozantinib, and are awaiting clinical trials [10]. Other receptor-binding inhibitors, such as cetuximab, work differently from the TKIs gefitinib and erlotinib. However, erlotinib and gefitinib alone show poor response rates (5-10\%) in EOC $[11,108]$ owing to PI3K-pathway-mediated tumor resistance through p38 MAPK acti- 
vation and the following DNA repair [109]. Thus, targeting of EGFR, along with inhibition of p38 MAPK or DNA repair, may improve the efficacy of EGFR mediated treatment in ovarian cancer.

\subsection{Ansamycins and HSP90 Degradation}

Benzoquinone ansamycin 17-allylamino-17-demethoxygeldanamycin (17-AAG) is an early described tyrosine kinase inhibitor that interacts with HSP90, leading to the proteasomal degradation of Hsp90-targeted proteins [110,111]. Many biological functions of 17-AAG are common with those of its parent compound geldanamycin (GA), including the ability to inhibit the growth of tumor cells [112]. It has been shown that Hsp90 originating from tumor cells has a 100-fold higher affinity to bind with 17-AAG than Hsp90 from normal cells, and also a strong affinity for oncogenic signaling proteins such as HER2/ErbB2, Akt, Raf-1, mutated p53, and Bcr-Abl, emphasizing it as an attractive candidate for new treatment options in OC. For example, ErbB2 appears to be a potential target, because high ErbB2-expressing cells are more susceptible to ansamycin-induced growth inhibition at minimal doses. Surprisingly, this effect seems to be linked to ErbB3- and PI3K/AKT-dependent pathways [113]. Ansamycins are known to have a strong affinity for the AKT protein. For AKT to remain stable, HSP90 needs to be linked to it, and the addition of HSP90 inhibitors results in a gradual decrease in AKT function [114,115]. Thus, the PI3K-AKT signaling pathway is highly active in the progression of $\mathrm{OC}$, and combination therapy of 17-AAG with cisplatin or taxol may enhance cell apoptosis via the inhibition of $\mathrm{PI} 3 \mathrm{~K} / \mathrm{Akt}$ signaling. In addition, the combination of olaparib and 17-AAG may increase drug sensitivity in HR-proficient EOC and reverse multidrug resistance [116], suggesting the rational use of $17-\mathrm{AAG}$ in ovarian cancer.

\section{5. $26 S$ Proteosome Inhibition with PS341 (Bortezomib)}

The activity of the proteasome directly represents a promising therapeutic strategy for cancer. PS341 (bortezomib), a dipeptide boronic acid derivative, prevents protein degradation by the reversible inhibition of the $20 \mathrm{~S}$ proteasome. Cyclins (CDKs) and IkB proteins, which are corepressors of nuclear factor-kappa B (NF-kB) activation, seem to be the prospective targets. The inhibition of IkB degradation reduces NF- $\mathrm{B}$ transcription factor activity [117]. Although NF-kB appears to have a strong antiapoptotic function, the use of PS-341 and NF-кB blockers tends to increase chemotherapy-induced apoptosis.

\subsection{Tubulin-Targeting Molecules}

Anticancer drugs, including taxanes and vinca alkaloids, which are directed against microtubules, have long been used as first-line drugs for breast cancer and a wide range of other cancers, including ovarian, prostate, head and neck, and lung cancers [86]. Polyglutamated paclitaxel (CT2103), a cytotoxic agent, was found to have fewer side effects and better treatment responses than paclitaxel in phase III clinical trials [118]. Compared to the original paclitaxel, this new formulation has a decreased risk of hypersensitive side effects and can be administered more quickly. Indeed, it shows taxane-like efficacy in recurrent OC, with a response rate of $23 \%$ in individuals who have received limited prior therapy; however, oral treatment results in low bioavailability [119].

\subsection{Ovarian Cancer-Specific Targets: MUC16/CA125}

For more than two decades since its discovery, CA125 antigen has been permitted for clinical use for the OC screening of high-risk women in the US. Later, it was suggested as a predictive marker in preinvasive OC [120]. Although it has limited sensitivity and specificity, the CA125 antigen is strongly related to epithelial OC. The diagnostic performance of this biomarker has been useful in primary care, especially in women $\geq 50$ years old [121]. Lloyd and colleagues identified the gene that encodes the CA125 antigen, which was subsequently called MUC16 [122]. The affinity for the binding of CA125 antigen with the murine monoclonal antibody Mab-B3.13 (also known as OvaRex) is strong. Thus, CA125-targeted 
murine antibodies have been employed as potential therapeutic agents. In a phase I/II clinical trial, patients with recurrent OC developed immunity, such as antibodies and $\mathrm{T}$ cells, to oregovomab and CA125 given as third-line therapy, and anti-idiotype antibodies were found in $66 \%$ of patients $[123,124]$. This suggests that vaccination using specific anti-idiotypic antibodies could ameliorate the survival benefit for patients with few side effects in recurrent OC. Therefore, the application of the noninvasive immunotherapy in combination chemotherapy may be a potential therapeutic strategy for improved survival in OC [125].

\section{Drug-Delivery System for Ovarian Cancer Treatment}

Treating OC using traditional chemotherapy has serious limitations, including the rapid clearance of drugs, undesirable biodistribution, and adverse side effects. To minimize these limitations, researchers have focused on a variety of drug delivery systems (DDSs) with which to encapsulate anticancer agents so they can directly reach tumor cells. Many types of DDSs have been developed, such as liposomes, drug conjugates, microspheres, micelles, nanoparticles, implants, and injection depots [126]. The benefits of using a DDS over conventional chemotherapy include the lower nonspecific toxicity, increased exposure of cancer cells to the drugs, circumvention of drug resistance, and improved drug solubility.

In 1996, researchers published the first report on biodegradable and biocompatible nanoparticle compositions using poly(lactic-co-glycolic) acid. Various improvements and adjustments have been made to the material, and nanoparticle synthesis processes have been continually updated. Recently, there has been growing interest in employing naturally existing protein cages, such as viral particles, as drug carriers [127-129], while the majority of research has focused on designing nanoparticles for delivering chemotherapeutic agents such as cisplatin, doxorubicin, and paclitaxel as an advanced therapeutic option for OC [130]. The polymers most widely used in drug delivery systems include polylactic acid (PLA), polylactic-co-glycolic acid (PLGA), poly( $\gamma$-glutamylglutamine), polyethylene oxide, modified poly $-\varepsilon$-caprolactone (PCL), and polypropylenimine (PPI) [130-132]. In addition to designing diverse nanoparticle materials, it is possible to make various surface modifications to either sustain the controlled release of drugs or enhance drug stability [133].

\subsection{Single-Agent Delivery Systems}

To enhance the efficacy of cancer treatment, a minimum of one chemotherapeutic agent is encapsulated or embedded into nanoparticles. The drug cisplatin is widely used as first-line therapy for ovarian cancer, but it has a dose restriction due to its nephrotoxicity [134]. Therefore, researchers have made efforts to improve the distribution of cisplatin and reduce kidney damage by using surface modification and nanoparticle engineering techniques $[135,136]$. Polyisobutylene-maleic acid (PIMA) linked to glucosamine (GA) was used to generate cisplatin nanoparticles by forming platinum $(\mathrm{Pt})$ complexes toward each monomeric unit at various polymer-to-Pt ratios [135].

The chemotherapeutic agent paclitaxel is widely used in combination with a therapeutic drug carrier, but the small molecule is hydrophobic in nature (DrugBank, DB01229). To overcome the obstacle of its low aqueous solubility, the clinical dosage is used with absolute ethanol, making a combination called Cremophor EL, which is physiologically and pharmacologically potent; however, it has been shown to cause severe acute hypersensitivity [137]. ABI-007 (Abraxane ${ }^{\circledR}$ ), an alternative to Cremophor EL, was later developed to improve the solubility of paclitaxel [138], and an albumin-bound paclitaxel nanomaterial was approved by the FDA for treating different types of cancers [139]. It is now a feasible alternative to paclitaxel in Cremophor EL drug formulations. Feng et al. developed nanoparticles comprising paclitaxel joined to PGG via an ester bond [140].

In addition to breast cancer treatment, the chemotherapeutic drug doxorubicin (Dox) is also extensively used in ovarian cancer, but it presents serious cardiotoxicity. To lessen its toxicity, doxorubicin could be encapsulated and delivered via a drug delivery system. 
Zeng et al. developed a naturally occurring biological scaffold for synthesizing doxorubicinreleasing nanoparticles by infecting the cucumber mosaic virus (CMV) [141].

\subsection{Co-Delivery Nanoparticles}

To achieve superior efficacy, particularly in chemotherapy, and minimize the toxicity of single-drug therapy, nanodrug co-delivery systems (NDCDSs) have been developed, using combinations of at least two anticancer drugs with different physicochemical and pharmacological properties [142]. It is possible to incorporate drugs, antibodies, and siRNA into the nanoparticles, facilitating the administration of numerous drugs in a single dose. For example, paclitaxel and ceramide were co-delivered utilizing PEO-PCL nanoparticles $[143,144]$. Ceramide buildup within cancer cells induces apoptosis and enhances the effectiveness of chemotherapy. However, ceramide cannot be administered to the systemic circulation due to its hydrophobicity, limited cell permeability, and metabolic inactivity. Therefore, biocompatible and biodegradable nanoparticles with paclitaxel and ceramide co-delivery were developed for effective ovarian cancer treatment.

There have also been significant developments in siRNA-based drug co-delivery systems. By using polypropylenimine (PPI), a new dendrimer that efficiently transported paclitaxel and a siRNA specific for the CD44 mRNA was synthesized [145-147]. CD44, a glycoprotein present on the membranes of cancer cells, plays an essential role in cancer development and progression. It was expected that the siRNA-mediated inhibition of the cell surface CD44 marker would prevent the development of metastasis and improve the efficacy of chemotherapy treatment. A delivery vehicle was developed to overcome the slow penetration of siRNA into the cell membrane. A polypropylenimine (PPI) dendrimer was designed along with the chemotherapeutic drug paclitaxel to deliver siRNA for CD44 suppression [146]. However, the issues of biodegradation, bioavailability, instability, tissue distribution, and possible toxicity raise concerns about their safety for long-term administration [148].

\section{Limitations and Chemoresistance of Ovarian Cancer Therapy}

More than half (58\%) of OC patients are diagnosed at an advanced stage (III or IV), which prevents early diagnosis and leads to poor prognosis [149]. The standard of care for advanced OC includes cytoreductive tumor surgery followed by chemotherapy and/or radiotherapy regardless of tumor heterogeneity, hormone therapy, etc. [150]. However, chemotherapy resistance is still considered a major challenge when attempting to cure patients and achieve a favorable prognosis because the exact treatment choice depends on a number of factors, including the cancer molecular subtype, stemness, and clinical stage; the disease dynamics; and the person's age and overall health [151].

A variety of chemotherapeutic agents for treating ovarian cancer that can be used singly or in combination are available $[13,152]$. The most commonly used chemotherapeutic agents are platinum-based drugs (cisplatin and carboplatin) and taxane family drugs (paclitaxel and docetaxel) [153]. Unfortunately, these agents are associated with different types of life-threatening side effects, including sustained nausea and vomiting, hair loss, mouth sores, acute renal injury, ototoxicity, infertility, anemia, leukopenia, thrombocytopenia, and long-term peripheral neuropathy [9]. In fact, chemotherapeutic agents have poor bioavailability, high dose requirements, low therapeutic indices, and nonspecific targeting, which ultimately lead to elevated toxicity in normal cells and drug resistance in cancer cells [148].

Chemotherapy resistance is a complex phenomenon in which cancer cells evade the effects of chemotherapeutics. Multidrug resistance (MDR) is considered the main cause of chemotherapy treatment failure and low patient survival rates [154]. With MDR, cancer cells become insensitive to both cytostatic drugs and pharmaceutical agents. The resistance emerges rapidly through multiple mechanisms such as drug inactivation, alterations in the drug target, drug efflux (e.g., P-glycoprotein), DNA damage repair, the evasion of apoptosis [154], the activation of drug-metabolizing enzymes (e.g., cytochrome P450 
and glutathione S-transferase) [155], and genetic (gene mutation and amplification) and epigenetic (methylation and acetylation) changes [154]. Among these mechanisms, some favor drug resistance by reducing the effective concentrations, while others contribute by inhibiting the toxic action of the drugs [156]. However, due to advancements in DNA microarrays, proteomics technology, and the development of novel targeted therapeutics, new strategies for overcoming drug resistance can be provided.

Radiotherapy has been used extensively for the treatment of dysgerminomas and the clearance of residual malignancy after surgical removal. However, despite the therapeutic effects with regard to the clinical management of ovarian cancer, the development of resistance is apparently unavoidable, which impedes further treatment [157]. Therefore, understanding the underlying molecular mechanism of therapeutic resistance is crucial in the management of ovarian cancer and drug discovery, which will improve clinical outcomes.

\section{Technological Advances in Identifying Novel Biomarkers of Ovarian Cancer}

Despite the widespread use of traditional and modern technology for the detection and prognosis of OC, it remains the deadliest gynecological malignancy in terms of early diagnosis and management [150]. Therefore, it is urgent to search for novel diagnostic and prognostic biomarkers of ovarian cancer in order to understand the disease's biology, which could provide guidance for improved treatment decisions. Currently, multi-omics approaches (genomics, transcriptomics, proteomics, and metabolomics) provide unprecedented opportunities to understand disease pathophysiology at different molecular layers, which can facilitate the accurate prediction of disease biology. The molecular markers identified by these approaches are crucial for disease prognosis by predicting tumorigenesis, progression, and metastasis, based on the continuous improvement of the technologies $[16,17,158-160]$. The discovery of novel biomarkers could guide targeted therapeutic decisions by accurate prognostication, thereby minimizing unwanted side effects and therapy resistance, which could improve the management of ovarian cancer toward achieving a better quality of life and patient survival outcomes (Table 1) [161-163].

Table 1. Emerging prognostic biomarkers in ovarian cancer and novel technologies.

\begin{tabular}{|c|c|c|c|c|c|c|}
\hline $\begin{array}{l}\text { Biomarker/ } \\
\text { Drug/ } \\
\text { Inhibitor }\end{array}$ & $\begin{array}{l}\text { Treatment Strategies/ } \\
\text { Components }\end{array}$ & $\begin{array}{l}\text { Therapeutic } \\
\text { Response }\end{array}$ & $\begin{array}{l}\text { Features/ } \\
\text { Properties/ } \\
\text { Nature }\end{array}$ & $\begin{array}{l}\text { Detection } \\
\text { Level }\end{array}$ & $\begin{array}{l}\text { Supported } \\
\text { Technologies }\end{array}$ & Refs. \\
\hline PARP inhibitor & Extended PFS & $\begin{array}{c}\text { OC, } \\
\text { phase } 3 \text { trial }\end{array}$ & Personalized medicine & HRD-positive tumors & & [164-166] \\
\hline $\begin{array}{l}\text { PARP inhibitor, } \\
\text { bevacizumab }\end{array}$ & PFS benefit, anti-VEGF & $\begin{array}{c}\text { OC, } \\
\text { phase } 3 \text { trial }\end{array}$ & Antiangiogenic & $\begin{array}{l}\text { HRD-positive tumors, } \\
\text { BRCA mutation }\end{array}$ & & [100] \\
\hline Combination of PARP and ATR inhibitor & $\begin{array}{l}\text { Overcomes PARPi and } \\
\text { platinum resistance }\end{array}$ & OC, PDX models & $\begin{array}{l}\text { Stabilize stressed replication } \\
\text { fork and apoptosis }\end{array}$ & DNA, protein & $\begin{array}{l}\text { Western blot, IHC, } \\
\text { NGS, RPPA }\end{array}$ & [17] \\
\hline ARNTL & $\begin{array}{l}\text { Epi-biomarker by reducing } \\
\text { promoter methylation }\end{array}$ & OC & $\begin{array}{c}\text { Circadian and } \\
\text { tumor-suppressor gene }\end{array}$ & DNA & $\begin{array}{l}\text { CpG island microarray, } \\
\text { COBRA, ChIP-PCR }\end{array}$ & {$[167,168]$} \\
\hline RUNX3/CAMK2N1 & $\begin{array}{l}\text { Epigenetic prognostic } \\
\text { marker }\end{array}$ & EOC & $\begin{array}{l}\text { Hypermethylation of CpG } \\
\text { island reduces PFS }\end{array}$ & DNA & $\begin{array}{l}\text { GWA and targeted NGBS } \\
\text { confirming array }\end{array}$ & {$[162,169]$} \\
\hline Fkbp1/Pax9 & $\begin{array}{l}\text { Epi-biomarker for } \\
\text { platinum-resistant } \\
\text { therapeutic target }\end{array}$ & $\mathrm{OC}$ & $\begin{array}{l}\text { PAX9 hypermethylation } \\
\text { causes a poor prognosis for } \\
\text { OS }\end{array}$ & $\begin{array}{l}\text { DNA, } \\
\text { RNA }\end{array}$ & Sanger sequencing, RT-PCR & [161] \\
\hline COL11A1 & $\begin{array}{c}\text { Promotes tumor } \\
\text { progression through } \\
\text { TGF- } \beta 1 \text {-MMP3 axis and } \\
\text { predicts poor prognosis }\end{array}$ & $\mathrm{OC}$ & $\begin{array}{l}\text { Disease-progression- } \\
\text { associated gene }\end{array}$ & mRNA & $\begin{array}{l}\text { Microarray, RT-PCR, casein } \\
\text { zymography, and } \\
\text { ChIP assay }\end{array}$ & [170] \\
\hline circCELSR1 & $\begin{array}{l}\text { Increases paclitaxel } \\
\text { resistance and } \\
\text { poor prognosis }\end{array}$ & OC & Circular RNA & miRNA & $\begin{array}{l}\text { Microarray analysis } \\
\text { and RT-qPCR }\end{array}$ & [171] \\
\hline microRNA-137 & $\begin{array}{l}\text { Promotes apoptosis; } \\
\text { represses mRNA translation }\end{array}$ & $\begin{array}{l}\text { Improves drug } \\
\text { resistance }\end{array}$ & Regulating RNA & $\begin{array}{c}\text { Short non-coding } \\
\text { RNA }\end{array}$ & $\begin{array}{l}\text { Dual-luciferase reporter } \\
\text { assay }\end{array}$ & [158] \\
\hline FOXM1 & $\begin{array}{l}\text { Prognostic and } \\
\text { chemoresistant } \\
\text { therapeutic target }\end{array}$ & Non-serous EOC & Oncogene & $\mathrm{mRNA}$, protein & $\begin{array}{l}\text { Microarray, RT-qPCR, } \\
\text { and IHC }\end{array}$ & [163] \\
\hline RBP4 & $\begin{array}{c}\text { Diagnostic or } \\
\text { prognostic biomarker }\end{array}$ & $\begin{array}{c}\text { Ovarian } \\
\text { endometrioma }\end{array}$ & $\begin{array}{l}\text { Adipokine RBP4 involved } \\
\text { in the pathogenesis of } \\
\text { endometriosis }\end{array}$ & Protein & $\begin{array}{l}\text { Human XL proteome profile } \\
\text { assay, IHC, cell viability, } \\
\text { and invasiveness assay }\end{array}$ & [172] \\
\hline
\end{tabular}


Table 1. Cont.

\begin{tabular}{|c|c|c|c|c|c|c|}
\hline $\begin{array}{l}\text { Biomarker/ } \\
\text { Drug/ } \\
\text { Inhibitor }\end{array}$ & $\begin{array}{l}\text { Treatment Strategies/ } \\
\text { Components }\end{array}$ & $\begin{array}{l}\text { Therapeutic } \\
\text { Response }\end{array}$ & $\begin{array}{l}\text { Features/ } \\
\text { Properties/ } \\
\text { Nature }\end{array}$ & $\begin{array}{l}\text { Detection } \\
\text { Level }\end{array}$ & $\begin{array}{l}\text { Supported } \\
\text { Technologies }\end{array}$ & Refs. \\
\hline AAT, NFKB, PMVK, VAP1, FABP4, and PF4 & Predicts prognosis & HGSOC & $\begin{array}{c}\text { Differentially } \\
\text { expressed proteins }\end{array}$ & Protein & $\begin{array}{l}\text { Hierarchical clustering, } \\
\text { bioinformatics, LC-MS, } \\
\text { and IHC }\end{array}$ & [19] \\
\hline $\begin{array}{l}\text { Serotransferrin, amyloid A1, hemopexin, } \\
\text { C-reactive protein, albumin }\end{array}$ & $\begin{array}{l}\text { Multimarker test specific for } \\
\text { screening and detection } \\
\text { of OC }\end{array}$ & OC & $\begin{array}{l}\text { Molecular signaling } \\
\text { pathways of } O C\end{array}$ & Protein & $\begin{array}{l}\text { ITRAQ-tagging coupled } \\
\text { with mass spectrometry }\end{array}$ & [16] \\
\hline PDGFR-beta and VEGFR-2 & $\begin{array}{l}\text { Predictive biomarker for } \\
\text { treatment response }\end{array}$ & $\mathrm{OC}$ & $\begin{array}{l}\text { Angiogenesis-related } \\
\text { growth factor receptors }\end{array}$ & $\begin{array}{l}\text { mRNA } \\
\text { Protein }\end{array}$ & $\begin{array}{c}\text { Quantitative RPPA, } \\
\text { bioinformatic analysis }\end{array}$ & [173] \\
\hline Circulatory protein & $\begin{array}{l}\text { Personalized therapy for } \\
\text { early diagnosis and } \\
\text { prediction of } \\
\text { drug resistance }\end{array}$ & $\mathrm{OC}$ & Proteomic landscape & Protein & Proteomic & [174] \\
\hline $\begin{array}{l}\text { 2-piperidinone and } \\
\text { 1-heptadecanoylglycerophosphoethanolamine }\end{array}$ & $\begin{array}{l}\text { Clinical diagnosis } \\
\text { and treatment }\end{array}$ & OC & Candidate biomarker & Metabolites & UPLC/Q-TOF MS & [159] \\
\hline
\end{tabular}

In genomics, oncogenes, tumor-suppressor genes, and epigenetic modifications of DNA can be detected at the DNA level through gene mutation and DNA methylation microarrays, genome-wide association studies, and sequencing $[163,167,175]$. The mutation of TP53 is the most frequent genetic abnormality; it causes loss of function in OC and is demonstrated in $60-80 \%$ of patients in both sporadic and familial cases [4]. DNA repair defects were found in $10-15 \%$ of ovarian cancers; the lifetime risk for BRCA1 is about $30-60 \%$ and that for BRCA2 is $15-30 \%$ in those who have a genetic defect promoting the development of OC [4]. In addition, the epi-biomarkers RUNX3/CAMK2N1, ARNTL, and Fkbp1/Pax9, detected by GWA, CpG island microarrays, ChIP-PCR, and Sanger sequencing, can predict prognosis, clinical outcomes, and chemotherapy resistance [161,162,167].

In transcriptomics, coding mRNA and ncRNA microarrays and RT-qPCR are widely used to explore disease biology and dynamics with a comprehensive assessment of changes in expression patterns by observing the differential expression of genes and differently spliced transcripts at the RNA level, including mRNA, miRNAs, lncRNAs, and circRNAs in ovarian cancer (Table 1). In some cases, high collagen type XI alpha 1 (COL11A1) expression at the mRNA level is associated with advanced disease stage, recurrence, and poor survival via the TGF- $\beta 1-$ MMP3 axis and pathways [170]. The forkhead box M1 (FOXM1) oncogene is upregulated (mRNA) in EOC; it is involved in cell cycle progression predominantly through the regulation of cell-cycle-checkpoint genes and is a potential prognostic biomarker for chemoresistant OC [163]. The circCELSR1, a circular RNA (circRNA), was found to be dramatically upregulated in PTX-resistant OC, as determined by microarray analysis and quantitative real-time PCR, dual-luciferase reporter assays, and RNA immunoprecipitation, and the circCELSR1-miR-1252-FOXR2 axis was finally established as a novel therapeutic target in OC [158].

Regarding protein levels, differentially expressed proteins, antibodies, cytokines, growth factors (proliferating and proangiogenic factors), etc., could be very useful in the early diagnosis and prognosis of OC through high-throughput techniques such as LC-MS, ITRAQ tagging coupled with mass spectrometry, reverse-phase protein arrays, etc. $[16,19,172,173]$. For example, serotransferrin, AA1, Hpx, CRP, and albumin, found to be differentially expressed in OC, can be used in a multimarker test for the screening and detection of ovarian cancer [16]. Retinol-binding protein 4 (RBP4) is an adipocytederived cytokine that contributes to the pathogenesis of endometriosis by increasing the viability, proliferation, and invasion of endometrial stromal cells [172]. Therefore, novel efficient diagnostic platforms are needed to detect OC biomarkers with high sensitivity and selectivity, miniaturization, versatility, and high throughput. The identification of new biomarkers for early diagnosis is also required in order to increase the survival rate and quality of life of ovarian cancer patients.

\section{Conclusions}

Ovarian cancer is a deadly gynecological illness that affects women worldwide. Due to a lack of precise diagnostic biomarkers, the majority of women with ovarian cancer are 
diagnosed at an advanced stage, which reduces their chances of survival. Chemotherapy resistance in late-stage ovarian cancer is a significant clinical challenge, because various signaling pathways are involved in the pathophysiology of chemotherapy resistance. In order to address this, the focus is on developing biomarkers and diagnostic tools that can help with the early detection and prediction of the disease. It is hard to determine the molecular changes occurring in ovarian cancer, which is very important for choosing the right therapeutic drugs, the success of which can improve clinical outcomes. Thus, it is critical to understand the biology of this heterogeneous disease in order to conduct more precise investigations into its mechanisms. Advancements in our understanding of ovarian cancer biology has resulted in the identification of a variety of molecular targets, including signal transduction pathways, growth factor receptors, angiogenic processes, and cell cycle regulators, as well as drug delivery systems. In addition, advances in therapeutic technology have allowed significant insight into the molecular complexity, creating opportunities for diagnosis and prognosis to inform new therapeutic efforts which have the potential to significantly improve the overall survival rate and quality of life of patients with ovarian cancer.

Author Contributions: S.A. and M.A.R. were substantially involved in the conception and design of the work. M.N.H. (Mohammad Nazmul Hasan), H.A., M.A.R., P.N., R.I., Y.S., M.S.G., M.N.H. (Md Nazmul Huda), J.C. and S.H. prepared the original draft. M.H.R., H.A. and S.A. provided the figures and table. S.S.K., T.G.C., N.M.N., J.H., B.K., I.K., W.C. and S.A. reviewed and edited the manuscript. All authors have read and agreed to the published version of the manuscriptt.

Funding: This work was supported by National Research Foundation of Korea (NRF) grants funded by the Korean government (MEST) (NRF-2020R1I1A1A01069013 to TGC, and NRF-2018R1A6A1A03025124 and NRF-2020H1D3A1A04080389 to SSK).

Institutional Review Board Statement: Not applicable.

Informed Consent Statement: Not applicable.

Data Availability Statement: Not applicable.

Conflicts of Interest: The authors declare no conflict of interest.

\section{References}

1. Ahmed, N.; Kadife, E.; Raza, A.; Short, M.; Jubinsky, P.T.; Kannourakis, G. Ovarian Cancer, Cancer Stem Cells and Current Treatment Strategies: A Potential Role of Magmas in the Current Treatment Methods. Cells 2020, 9, 719. [CrossRef] [PubMed]

2. Lengyel, E. Ovarian Cancer Development and Metastasis. Am. J. Pathol. 2010, 177, 1053-1064. [CrossRef] [PubMed]

3. Yang, M.Q.; Elnitski, L. A Systems Biology Comparison of Ovarian Cancers Implicates Putative Somatic Driver Mutations through Protein-Protein Interaction Models. PLoS ONE 2016, 11, e0163353. [CrossRef]

4. Bast, R.C., Jr.; Hennessy, B.; Mills, G.B. The biology of ovarian cancer: New opportunities for translation. Nat. Rev. Cancer 2009, 9, 415-428. [CrossRef] [PubMed]

5. Marcus, C.S.; Maxwell, G.L.; Darcy, K.M.; Hamilton, C.A.; McGuire, W.P. Current Approaches and Challenges in Managing and Monitoring Treatment Response in Ovarian Cancer. J. Cancer 2014, 5, 25-30. [CrossRef] [PubMed]

6. Brand, D.V.D.; Mertens, V.; Massuger, L.F.; Brock, R. siRNA in ovarian cancer-Delivery strategies and targets for therapy. J. Control. Release 2018, 283, 45-58. [CrossRef] [PubMed]

7. Fabbro, M.; Colombo, P.-E.; Leaha, C.M.; Rouanet, P.; Carrère, S.; Quenet, F.; Gutowski, M.; Mourregot, A.; D’Hondt, V.; Coupier, I.; et al. Conditional Probability of Survival and Prognostic Factors in Long-Term Survivors of High-Grade Serous Ovarian Cancer. Cancers 2020, 12, 2184. [CrossRef] [PubMed]

8. Marchetti, C.; Pisano, C.; Facchini, G.; Bruni, G.S.; Magazzino, F.P.; Losito, S.; Pignata, S. First-line treatment of advanced ovarian cancer: Current research and perspectives. Expert Rev. Anticancer Ther. 2010, 10, 47-60. [CrossRef]

9. Feliu, J.; Heredia-Soto, V.; Gironés, R.; Jiménez-Munarriz, B.; Saldaña, J.; Guillén-Ponce, C.; Molina-Garrido, M.J. Management of the toxicity of chemotherapy and targeted therapies in elderly cancer patients. Clin. Transl. Oncol. 2020, 22, 457-467. [CrossRef] [PubMed]

10. Scott, A.J.; Arcaroli, J.J.; Bagby, S.M.; Yahn, R.; Huber, K.M.; Serkova, N.J.; Nguyen, A.; Kim, J.; Thorburn, A.; Vogel, J.; et al. Cabozantinib Exhibits Potent Antitumor Activity in Colorectal Cancer Patient-Derived Tumor Xenograft Models via Autophagy and Signaling Mechanisms. Mol. Cancer Ther. 2018, 17, 2112-2122. [CrossRef] [PubMed]

11. Ye, D.; Mendelsohn, J.; Fan, Z. Augmentation of a humanized anti-HER2 mAb 4D5 induced growth inhibition by a hu-man-mouse chimeric anti-EGF receptor mAb C225. Oncogene 1999, 18, 731-738. [CrossRef] [PubMed] 
12. Peracchio, C.; Alabiso, O.; Valente, G.; Isidoro, C. Involvement of autophagy in ovarian cancer: A working hypothesis. J. Ovarian Res. 2012, 5, 22. [CrossRef] [PubMed]

13. Wang, Q.; Peng, H.; Qi, X.; Wu, M.; Zhao, X. Targeted therapies in gynecological cancers: A comprehensive review of clinical evidence. Signal. Transduct. Target. Ther. 2020, 5, 1-34. [CrossRef] [PubMed]

14. Doi, T.; Boku, N.; Onozawa, Y.; Takahashi, K.; Kawaguchi, O.; Ohtsu, A. Phase I dose-escalation study of the safety, tolerability, and pharmacokinetics of aflibercept in combination with S-1 in Japanese patients with advanced solid malignancies. Investig. New Drugs 2020, 38, 1390-1399. [CrossRef] [PubMed]

15. Thouvenin, L.; Charrier, M.; Clement, S.; Christinat, Y.; Tille, J.-C.; Frigeri, M.; Homicsko, K.; Michielin, O.; Bodmer, A.; Chappuis, P.O.; et al. Ovarian cancer with high-level focal ERBB2 amplification responds to trastuzumab and pertuzumab. Gynecol. Oncol. Rep. 2021, 37, 100787. [CrossRef] [PubMed]

16. Swiatly, A.; Horala, A.; Matysiak, J.; Hajduk, J.; Nowak-Markwitz, E.; Kokot, Z.J. Understanding Ovarian Cancer: iTRAQ-Based Proteomics for Biomarker Discovery. Int. J. Mol. Sci. 2018, 19, 2240. [CrossRef]

17. Kim, H.; Xu, H.; George, E.; Hallberg, D.; Kumar, S.; Jagannathan, V.; Medvedev, S.; Kinose, Y.; Devins, K.; Verma, P.; et al. Combining PARP with ATR inhibition overcomes PARP inhibitor and platinum resistance in ovarian cancer models. Nat. Commun. 2020, 11, 1-16. [CrossRef]

18. Matondo, A.; Jo, Y.H.; Shahid, M.; Choi, T.G.; Nguyen, M.N.; Nguyen, N.N.Y.; Akter, S.; Kang, I.; Ha, J.; Maeng, C.H.; et al. The Prognostic 97 Chemoresponse Gene Signature in Ovarian Cancer. Sci. Rep. 2017, 7, 9689. [CrossRef]

19. Kim, S.I.; Jung, M.; Dan, K.; Lee, S.; Lee, C.; Kim, H.S.; Chung, H.H.; Kim, J.-W.; Park, N.H.; Song, Y.-S.; et al. Proteomic Discovery of Biomarkers to Predict Prognosis of High-Grade Serous Ovarian Carcinoma. Cancers 2020, 12, 790. [CrossRef]

20. Terraneo, N.; Jacob, F.; Dubrovska, A.; Grünberg, J. Novel Therapeutic Strategies for Ovarian Cancer Stem Cells. Front. Oncol. 2020, 10, 319. [CrossRef]

21. De Ruysscher, D.; Niedermann, G.; Burnet, N.G.; Siva, S.; Lee, A.W.M.; Hegi-Johnson, F. Author Correction: Radiotherapy tox-icity. Nat. Rev. Dis. Primers 2019, 5, 15. [CrossRef]

22. Yang, L.; Shi, P.; Zhao, G.; Xu, J.; Peng, W.; Zhang, J.; Zhang, G.; Wang, X.; Dong, Z.; Chen, F.; et al. Targeting cancer stem cell pathways for cancer therapy. Signal. Transduct. Target. Ther. 2020, 5, 8. [CrossRef]

23. Xia, Q.; Xu, M.; Zhang, P.; Liu, L.; Meng, X.; Dong, L. Therapeutic Potential of Autophagy in Glioblastoma Treatment With Phosphoinositide 3-Kinase/Protein Kinase B/Mammalian Target of Rapamycin Signaling Pathway Inhibitors. Front. Oncol. 2020, 10, 572904. [CrossRef] [PubMed]

24. Mehta, V.B.; Besner, G.E. HB-EGF promotes angiogenesis in endothelial cells via PI3-kinase and MAPK signaling pathways. Growth Factors 2007, 25, 253-263. [CrossRef]

25. Osaki, M.; Oshimura, M.; Ito, H. PI3K-Akt pathway: Its functions and alterations in human cancer. Apoptosis 2004, 9, 667-676. [CrossRef] [PubMed]

26. Hennessy, B.T.; Smith, D.L.; Ram, P.; Lu, Y.; Mills, G.B. Exploiting the PI3K/AKT Pathway for Cancer Drug Discovery. Nat. Rev. Drug Discov. 2005, 4, 988-1004. [CrossRef] [PubMed]

27. Levine, D.A.; Bogomolniy, F.; Yee, C.J.; Lash, A.; Barakat, R.R.; Borgen, P.I.; Boyd, J. Frequent Mutation of the PIK3CA Gene in Ovarian and Breast Cancers. Clin. Cancer Res. 2005, 11, 2875-2878. [CrossRef] [PubMed]

28. Cai, J.; Xu, L.; Tang, H.; Yang, Q.; Yi, X.; Fang, Y.; Zhu, Y.; Wang, Z. The Role of the PTEN/PI3K/Akt Pathway on Prognosis in Epithelial Ovarian Cancer: A Meta-Analysis. Oncology 2014, 19, 528-535. [CrossRef] [PubMed]

29. Patch, A.-M.; Christie, E.; Etemadmoghadam, D.; Garsed, D.W.; George, J.; Fereday, S.; Nones, K.; Cowin, P.; Alsop, K.; Bailey, P.J.; et al. Whole-genome characterization of chemoresistant ovarian cancer. Nature 2015, 521, 489-494. [CrossRef] [PubMed]

30. Martorana, F.; Motta, G.; Pavone, G.; Motta, L.; Stella, S.; Vitale, S.R.; Manzella, L.; Vigneri, P. AKT Inhibitors: New Weapons in the Fight Against Breast Cancer? Front. Pharmacol. 2021, 12, 662232. [CrossRef]

31. Liu, R.; Chen, Y.; Liu, G.; Li, C.; Song, Y.; Cao, Z.; Li, W.; Hu, J.; Lu, C.; Liu, Y. PI3K/AKT pathway as a key link modulates the multidrug resistance of cancers. Cell Death Dis. 2020, 11, 1-12. [CrossRef]

32. Deng, J.; Bai, X.; Feng, X.; Ni, J.; Beretov, J.; Graham, P.; Li, Y. Inhibition of PI3K/Akt/mTOR signaling pathway alleviates ovarian cancer chemoresistance through reversing epithelial-mesenchymal transition and decreasing cancer stem cell marker expres-sion BMC Cancer 2019, 19, 618. [CrossRef] [PubMed]

33. Tran, A.Q.; Sullivan, S.A.; Chan, L.L.; Yin, Y.; Sun, W.; Fang, Z.; Dugar, S.; Zhou, C.; Bae-Jump, V. SPR965, a Dual PI3K/mTOR Inhibitor, as a Targeted Therapy in Ovarian Cancer. Front. Oncol. 2020, 10, 624498. [CrossRef] [PubMed]

34. Wen, W.; Liang, W.; Wu, J.; Kowolik, C.M.; Buettner, R.; Scuto, A.; Hsieh, M.Y.; Hong, H.; Brown, C.E.; Forman, S.J.; et al. Targeting JAK1/STAT3 signaling suppresses tumor progression and metastasis in a peritoneal model of human ovarian cancer. Mol. Cancer Ther. 2014, 13, 3037-3048. [CrossRef] [PubMed]

35. Thomas, S.J.; Snowden, J.A.; Zeidler, M.; Danson, S. The role of JAK/STAT signalling in the pathogenesis, prognosis and treatment of solid tumours. Br. J. Cancer 2015, 113, 365-371. [CrossRef]

36. Recio, C.; Guerra, B.; Guerra-Rodríguez, M.; Aranda-Tavío, H.; Martín-Rodríguez, P.; De Mirecki-Garrido, M.; Brito-Casillas, Y.; García-Castellano, J.M.; Estévez-Braun, A.; Fernández-Pérez, L. Signal transducer and activator of transcription (STAT)-5: An opportunity for drug development in oncohematology. Oncogene 2019, 38, 4657-4668. [CrossRef]

37. Sabaawy, H.E.; Ryan, B.M.; Khiabanian, H.; Pine, S.R. JAK/STAT of all trades: Linking inflammation with cancer development, tumor progression and therapy resistance. Carcinogenesis 2021, 42, 1411-1419. [CrossRef] 
38. Hu, X.; Li, J.; Fu, M.; Zhao, X.; Wang, W. The JAK/STAT signaling pathway: From bench to clinic. Signal. Transduct. Target. Ther. 2021, 6, 1-33. [CrossRef]

39. Zou, S.; Tong, Q.; Liu, B.; Huang, W.; Tian, Y.; Fu, X. Targeting STAT3 in Cancer Immunotherapy. Mol. Cancer 2020, 19, 1-19. [CrossRef]

40. Passamonti, F.; Griesshammer, M.; Palandri, F.; Egyed, M.; Benevolo, G.; Devos, T.; Callum, J.; Vannucchi, A.M.; Sivgin, S.; Bensasson, C.; et al. Ruxolitinib for the treatment of inadequately controlled polycythaemia vera without splenomegaly (RESPONSE-2): A randomised, open-label, phase 3b study. Lancet Oncol. 2016, 18, 88-99. [CrossRef]

41. Gritsina, G.; Xiao, F.; O’Brien, S.W.; Gabbasov, R.; Maglaty, M.A.; Xu, R.-H.; Thapa, R.J.; Zhou, Y.; Nicolas, E.; Litwin, S.; et al Targeted Blockade of JAK/STAT3 Signaling Inhibits Ovarian Carcinoma Growth. Mol. Cancer Ther. 2015, 14, 1035-1047. [CrossRef]

42. She, S.; Zhao, Y.; Kang, B.; Chen, C.; Chen, X.; Zhang, X.; Chen, W.; Dan, S.; Wang, H.; Wang, Y.J.; et al. Combined inhibition of JAK1/2 and DNMT1 by newly identified small-molecule compounds synergistically suppresses the survival and proliferation of cervical cancer cells. Cell Death Dis. 2020, 11, 724. [CrossRef]

43. Abubaker, K.; Luwor, R.B.; Escalona, R.; McNally, O.; Quinn, M.A.; Thompson, E.W.; Findlay, J.K.; Ahmed, N. Targeted Disruption of the JAK2/STAT3 Pathway in Combination with Systemic Administration of Paclitaxel Inhibits the Priming of Ovarian Cancer Stem Cells Leading to a Reduced Tumor Burden. Front. Oncol. 2014, 4, 75. [CrossRef] [PubMed]

44. van der Zee, M.; Sacchetti, A.; Cansoy, M.; Joosten, R.; Teeuwssen, M.; Heijmans-Antonissen, C.; Ewing-Graham, P.C.; Burger, C.W.; Blok, L.J.; Fodde, R. IL6/JAK1/STAT3 Signaling Blockade in Endometrial Cancer Affects the ALDHhi/CD126+ Stem-like Component and Reduces Tumor Burden. Cancer Res. 2015, 75, 3608-3622. [CrossRef]

45. Nakayamada, S.; Kubo, S.; Iwata, S.; Tanaka, Y. Recent Progress in JAK Inhibitors for the Treatment of Rheumatoid Arthritis BioDrugs 2016, 30, 407-419. [CrossRef]

46. Zhang, Y.; Wang, X. Targeting the Wnt/beta-catenin signaling pathway in cancer. J. Hematol. Oncol. 2020, 13, 165. [CrossRef] [PubMed]

47. Nusse, R.; Clevers, H. Wnt/ $\beta$-Catenin Signaling, Disease, and Emerging Therapeutic Modalities. Cell 2017, 169, 985-999. [CrossRef]

48. Jung, Y.S.; Park, J.I. Wnt signaling in cancer: Therapeutic targeting of Wnt signaling beyond beta-catenin and the destruction complex. Exp. Mol. Med. 2020, 52, 183-191. [CrossRef] [PubMed]

49. Teeuwssen, M.; Fodde, R. Wnt Signaling in Ovarian Cancer Stemness, EMT, and Therapy Resistance. J. Clin. Med. 2019, 8, 1658. [CrossRef]

50. Nguyen, V.H.L.; Hough, R.; Bernaudo, S.; Peng, C. Wnt/beta-catenin signalling in ovarian cancer: Insights into its hyperacti-vation and function in tumorigenesis. J. Ovarian Res. 2019, 12, 122. [CrossRef] [PubMed]

51. Chen, M.-W.; Yang, S.-T.; Chien, M.-H.; Hua, K.-T.; Wu, C.-J.; Hsiao, S.M.; Lin, H.; Hsiao, M.; Su, J.-L.; Wei, L.-H. The STAT3miRNA-92-Wnt Signaling Pathway Regulates Spheroid Formation and Malignant Progression in Ovarian Cancer. Cancer Res. 2017, 77, 1955-1967. [CrossRef] [PubMed]

52. Zannoni, G.F.; Angelico, G.; Santoro, A. Aberrant non-canonical WNT pathway as key-driver of high-grade serous ovarian cancer development. Virchows Arch. 2020, 477, 321-322. [CrossRef] [PubMed]

53. Doo, D.W.; Meza-Perez, S.; Londono, A.I.; Goldsberry, W.N.; Katre, A.A.; Boone, J.D.; Moore, D.J.; Hudson, C.T.; Betella, I.; McCaw, T.R.; et al. Inhibition of the Wnt/beta-catenin pathway enhances antitumor immunity in ovarian cancer. Ther. Adv. Med. Oncol. 2020, 12, 1758835920913798. [CrossRef] [PubMed]

54. Elmore, S. Apoptosis: A review of programmed cell death. Toxicol. Pathol. 2007, 35, 495-516. [CrossRef]

55. Obeng, E. Apoptosis (programmed cell death) and its signals-A review. Braz. J. Biol. 2021, 81, 1133-1143. [CrossRef] [PubMed]

56. Hengartner, M.O. The biochemistry of apoptosis. Nature 2000, 407, 770-776. [CrossRef]

57. Lowe, S.W.; Cepero, E.; Evan, G. Intrinsic tumour suppression. Nature 2004, 432, 307-315. [CrossRef]

58. Adams, J.M.; Cory, S. The Bcl-2 apoptotic switch in cancer development and therapy. Oncogene 2007, 26, 1324-1337. [CrossRef]

59. Tsujimoto, Y.; Finger, L.R.; Yunis, J.; Nowell, P.C.; Croce, C.M. Cloning of the Chromosome Breakpoint of Neoplastic B Cells with the $\mathrm{t}(14 ; 18)$ Chromosome Translocation. Science 1984, 226, 1097-1099. [CrossRef]

60. Hengartner, M.O. Apoptosis: Corralling the corpses. Cell 2001, 104, 325-328. [CrossRef]

61. Igney, F.H.; Krammer, P.H. Death and anti-death: Tumour resistance to apoptosis. Nat. Cancer 2002, 2, 277-288. [CrossRef] [PubMed]

62. Al-Alem, L.F.; Baker, A.T.; Pandya, U.M.; Eisenhauer, E.L.; Rueda, B.R. Understanding and Targeting Apoptotic Pathways in Ovarian Cancer. Cancers 2019, 11, 1631. [CrossRef] [PubMed]

63. Ueno, N.T.; Bartholomeusz, C.; Herrmann, J.L.; Estrov, Z.; Shao, R.; Andreeff, M.; Price, J.; Paul, R.W.; Anklesaria, P.; Yu, D.; et al E1A-mediated paclitaxel sensitization in HER-2/neu-overexpressing ovarian cancer SKOV3.ip1 through apoptosis in-volving the caspase-3 pathway. Clin. Cancer Res. 2000, 6, 250-259.

64. Brautigam, K.; Bauerschlag, D.O.; Weigel, M.T.; Biernath-Wupping, J.; Bauknecht, T.; Arnold, N.; Maass, N.; Meinhold-Heerlein, I Combination of enzastaurin and pemetrexed inhibits cell growth and induces apoptosis of chemoresistant ovarian cancer cells regulating extracellular signal-regulated kinase 1/2 phosphorylation. Transl. Oncol. 2009, 2, 164-173. [CrossRef]

65. Yasmeen, A.; Beauchamp, M.-C.; Piura, E.; Segal, E.; Pollak, M.; Gotlieb, W.H. Induction of apoptosis by metformin in epithelial ovarian cancer: Involvement of the Bcl-2 family proteins. Gynecol. Oncol. 2011, 121, 492-498. [CrossRef] 
66. Liu, Y.; Tong, L.; Luo, Y.; Li, X.; Chen, G.; Wang, Y. Resveratrol inhibits the proliferation and induces the apoptosis in ovarian cancer cells via inhibiting glycolysis and targeting AMPK/mTOR signaling pathway. J. Cell. Biochem. 2018, 119, 6162-6172. [CrossRef]

67. Wang, J.; Hansen, K.; Edwards, R.; Van Houten, B.; Qian, W. Mitochondrial division inhibitor 1 (mdivi-1) enhances death re-ceptor-mediated apoptosis in human ovarian cancer cells. Biochem Biophys Res. Commun 2015, 456, 7-12. [CrossRef]

68. Liu, L.; Fan, J.; Ai, G.; Liu, J.; Luo, N.; Li, C.; Cheng, Z. Berberine in combination with cisplatin induces necroptosis and apoptosis in ovarian cancer cells. Biol. Res. 2019, 52, 1-14. [CrossRef] [PubMed]

69. Rahman, M.A.; Rahman, M.S.; Rahman, M.H.; Rasheduzzaman, M.; Mamun-Or-Rashid, A.N.M.; Uddin, M.J.; Rahman, M.R.; Hwang, H.; Pang, M.G.; Rhim, H. Modulatory Effects of Autophagy on APP Processing as a Potential Treatment Target for Alzheimer's Disease. Biomedicines 2021, 9, 5. [CrossRef] [PubMed]

70. Rahman, M.A.; Rhim, H. Therapeutic implication of autophagy in neurodegenerative diseases. Bmb. Rep. 2017, 50, 345-354. [CrossRef]

71. Rahman, M.A.; Rahman, M.H.; Hossain, M.S.; Biswas, P.; Islam, R.; Uddin, M.J.; Rahman, M.H.; Rhim, H. Molecular Insights into the Multifunctional Role of Natural Compounds: Autophagy Modulation and Cancer Prevention. Biomedicines $2020,8,517$. [CrossRef] [PubMed]

72. Rahman, M.A.; Saha, S.K.; Rahman, M.S.; Uddin, M.J.; Uddin, M.S.; Pang, M.G.; Rhim, H.; Cho, S.G. Molecular Insights Into Therapeutic Potential of Autophagy Modulation by Natural Products for Cancer Stem Cells. Front. Cell. Dev. Biol. 2020, 8 , 283. [CrossRef]

73. Pu, Z.; Wu, L.; Guo, Y.; Li, G.; Xiang, M.; Liu, L.; Zhan, H.; Zhou, X.; Tan, H. LncRNA MEG3 contributes to adenosine-induced cytotoxicity in hepatoma HepG2 cells by downregulated ILF3 and autophagy inhibition via regulation PI3K-AKT-mTOR and beclin-1 signaling pathway. J. Cell Biochem. 2019, 120, 18172-18185. [CrossRef]

74. Cai, M.; Hu, Z.; Liu, J.; Gao, J.; Liu, C.; Liu, D.; Tan, M.; Zhang, D.; Lin, B. Beclin 1 Expression in Ovarian Tissues and Its Effects on Ovarian Cancer Prognosis. Int. J. Mol. Sci. 2014, 15, 5292-5303. [CrossRef] [PubMed]

75. Tasdemir, E.; Maiuri, M.C.; Galluzzi, L.; Vitale, I.; Djavaheri-Mergny, M.; D’Amelio, M.; Criollo, A.; Morselli, E.; Zhu, C.; Harper, F.; et al. Regulation of autophagy by cytoplasmic p53. Nat. Cell Biol. 2008, 10, 676-687. [CrossRef]

76. He, C.; Levine, B. The Beclin 1 interactome. Curr. Opin. Cell Biol. 2010, 22, 140-149. [CrossRef]

77. Liang, M.; Zhao, J. Protein expressions of AIB1, p53 and Bcl-2 in epithelial ovarian cancer and their correlations with the clinical pathological features and prognosis. Eur. Rev. Med. Pharmacol. Sci. 2018, 22, 5134-5139.

78. Lu, Z.; Luo, R.Z.; Lu, Y.; Zhang, X.; Yu, Q.; Khare, S.; Kondo, S.; Kondo, Y.; Yu, Y.; Mills, G.B.; et al. The tumor suppressor gene ARHI regulates autophagy and tumor dormancy in human ovarian cancer cells. J. Clin. Investig. 2008, 118, 3917-3929. [CrossRef] [PubMed]

79. Zhan, L.; Zhang, Y.; Wang, W.Y.; Song, E.X.; Fan, Y.J.; Li, J.; Wei, B. Autophagy as an emerging therapy target for ovarian car-cinoma. Oncotarget 2016, 7, 83476-83487. [CrossRef]

80. Abdallah, M.; El-Readi, M.; Althubiti, M.; Almaimani, R.; Ismail, A.; Idris, S.; Refaat, B.; Almalki, W.; Babakr, A.; Mukhtar, M.; et al. Tamoxifen and the PI3K Inhibitor: LY294002 Synergistically Induce Apoptosis and Cell Cycle Arrest in Breast Cancer MCF-7 Cells. Molecules 2020, 25, 3355. [CrossRef]

81. Shariati, M.; Meric-Bernstam, F. Targeting AKT for cancer therapy. Expert Opin. Investig. Drugs 2019, 28, 977-988. [CrossRef]

82. Wu, Y.; Gao, W.N.; Xue, Y.N.; Zhang, L.C.; Zhang, J.J.; Lu, S.Y.; Yan, X.Y.; Yu, H.M.; Su, J.; Sun, L.K. SIRT3 aggravates metfor-mininduced energy stress and apoptosis in ovarian cancer cells. Exp. Cell Res. 2018, 367, 137-149. [CrossRef] [PubMed]

83. Xiang, X.-Y.; Kang, J.-S.; Xue, Y.-N.; Yang, X.-C.; Su, J.; Wu, Y.; Yan, X.-Y.; Xu, Y.; Liu, Y.-H.; Yu, C.-Y.; et al. SIRT3 participates in glucose metabolism interruption and apoptosis induced by BH3 mimetic S1 in ovarian cancer cells. Int. J. Oncol. 2016, 49, 773-784. [CrossRef]

84. Banerjee, S.; Kaye, S.B. New Strategies in the Treatment of Ovarian Cancer: Current Clinical Perspectives and Future Potential. Clin. Cancer Res. 2013, 19, 961-968. [CrossRef] [PubMed]

85. Bonello, M.; Sims, A.H.; Langdon, S.P. Human epidermal growth factor receptor targeted inhibitors for the treatment of ovarian cancer. Cancer Biol. Med. 2018, 15, 375-388. [PubMed]

86. Škubník, J.; Pavlíčková, V.; Ruml, T.; Rimpelová, S. Current Perspectives on Taxanes: Focus on Their Bioactivity, Delivery and Combination Therapy. Plants 2021, 10, 569. [CrossRef]

87. Jain, R.K. Normalization of Tumor Vasculature: An Emerging Concept in Antiangiogenic Therapy. Science 2005, 307, 58-62. [CrossRef]

88. Kerbel, R.S. Tumor angiogenesis. N. Engl. J. Med. 2008, 358, 2039-2049. [CrossRef]

89. Lugano, R.; Ramachandran, M.; Dimberg, A. Tumor angiogenesis: Causes, consequences, challenges and opportunities. Cell Mol. Life Sci. 2020, 77, 1745-1770. [CrossRef]

90. Diaz-Flores, L.; Gutierrez, R.; Garcia-Suarez, M.P.; Saez, F.J.; Gutierrez, E.; Valladares, F.; Carrasco, J.L.; Diaz-Flores, L., Jr.; Madrid, J.F. Morphofunctional basis of the different types of angiogenesis and formation of postnatal angiogenesis-related secondary structures. Histol. Histopathol 2017, 32, 1239-1279.

91. Siveen, K.S.; Prabhu, K.; Krishnankutty, R.; Kuttikrishnan, S.; Tsakou, M.; Alali, F.; Dermime, S.; Mohammad, R.M.; Uddin, S. Vascular Endothelial Growth Factor (VEGF) Signaling in Tumour Vascularization: Potential and Challenges. Curr. Vasc. Pharmacol. 2017, 15, 339-351. [CrossRef] [PubMed] 
92. Tvorogov, D.; Anisimov, A.; Zheng, W.; Leppänen, V.-M.; Tammela, T.; Laurinavicius, S.; Holnthoner, W.; Heloterä, H.; Holopainen, T.; Jeltsch, M.; et al. Effective Suppression of Vascular Network Formation by Combination of Antibodies Blocking VEGFR Ligand Binding and Receptor Dimerization. Cancer Cell 2010, 18, 630-640. [CrossRef]

93. Ferrara, N.; Hillan, K.J.; Gerber, H.-P.; Novotny, W. Discovery and development of bevacizumab, an anti-VEGF antibody for treating cancer. Nat. Rev. Drug Discov. 2004, 3, 391-400. [CrossRef] [PubMed]

94. Hall, M.; Gourley, C.; McNeish, I.; Ledermann, J.; Gore, M.; Jayson, G.; Perren, T.; Rustin, G.; Kaye, S. Targeted anti-vascular therapies for ovarian cancer: Current evidence. Br. J. Cancer 2013, 108, 250-258. [CrossRef]

95. Pfisterer, J.; Shannon, C.M.; Baumann, K.; Rau, J.; Harter, P.; Joly, F.; Sehouli, J.; Canzler, U.; Schmalfeldt, B.; Dean, A.P.; et al Bevacizumab and platinum-based combinations for recurrent ovarian cancer: A randomised, open-label, phase 3 trial. Lancet Oncol. 2020, 21, 699-709. [CrossRef]

96. Pujade-Lauraine, E.; Hilpert, F.; Weber, B.; Reuss, A.; Poveda, A.; Kristensen, G.; Sorio, R.; Vergote, I.; Witteveen, P.; Bamias, A.; et al. Bevacizumab Combined With Chemotherapy for Platinum-Resistant Recurrent Ovarian Cancer: The AURELIA Open-Label Randomized Phase III Trial. J. Clin. Oncol. 2014, 32, 1302-1308. [CrossRef] [PubMed]

97. Aghajanian, C.; Blank, S.V.; Goff, B.A.; Judson, P.L.; Teneriello, M.G.; Husain, A.; Sovak, M.A.; Yi, J.; Nycum, L.R. OCEANS: A Randomized, Double-Blind, Placebo-Controlled Phase III Trial of Chemotherapy With or Without Bevacizumab in Patients With Platinum-Sensitive Recurrent Epithelial Ovarian, Primary Peritoneal, or Fallopian Tube Cancer. J. Clin. Oncol. 2012, 30, $2039-2045$. [CrossRef]

98. Perren, T.J.; Swart, A.M.; Pfisterer, J.; Ledermann, J.A.; Pujade-Lauraine, E.; Kristensen, G.; Carey, M.S.; Beale, P.; Cervantes, A.; Kurzeder, C.; et al. A Phase 3 Trial of Bevacizumab in Ovarian Cancer. N. Engl. J. Med. 2011, 365, 2484-2496. [CrossRef] [PubMed]

99. Burger, R.A.; Brady, M.F.; Bookman, M.A.; Fleming, G.F.; Monk, B.J.; Huang, H.; Mannel, R.S.; Homesley, H.D.; Fowler, J.; Greer B.E.; et al. Incorporation of Bevacizumab in the Primary Treatment of Ovarian Cancer. N. Engl. J. Med. 2011, 365, 2473-2483. [CrossRef]

100. Ray-Coquard, I.; Pautier, P.; Pignata, S.; Pérol, D.; González-Martín, A.; Berger, R.; Fujiwara, K.; Vergote, I.; Colombo, N.; Mäenpää, J.; et al. Olaparib plus Bevacizumab as First-Line Maintenance in Ovarian Cancer. N. Engl. J. Med. 2019, 381, 2416-2428. [CrossRef]

101. Lockhart, A.C.; Rothenberg, M.L.; Dupont, J.; Cooper, W.; Chevalier, P.; Sternas, L.; Buzenet, G.; Koehler, E.; Sosman, J.A.; Schwartz, L.H.; et al. Phase I study of intravenous vascular endothelial growth factor trap, aflibercept, in patients with advanced solid tumors. J. Clin. Oncol. 2010, 28, 207-214. [CrossRef] [PubMed]

102. Moasser, M.M. The oncogene HER2: Its signaling and transforming functions and its role in human cancer pathogenesis. Oncogene 2007, 26, 6469-6487. [CrossRef]

103. Muthuswamy, S.K.; Gilman, M.; Brugge, J.S. Controlled dimerization of ErbB receptors provides evidence for differential sig-naling by homo- and heterodimers. Mol. Cell Biol. 1999, 19, 6845-6857. [CrossRef] [PubMed]

104. Bookman, M.A.; Darcy, K.M.; Clarke-Pearson, D.; Boothby, R.A.; Horowitz, I.R. Evaluation of monoclonal humanized an-ti-HER2 antibody, trastuzumab, in patients with recurrent or refractory ovarian or primary peritoneal carcinoma with over-expression of HER2: A phase II trial of the Gynecologic Oncology Group. J. Clin. Oncol. 2003, 21, 283-290. [CrossRef] [PubMed]

105. Mamot, C.; Ritschard, R.; Wicki, A.; Stehle, G.; Dieterle, T.; Bubendorf, L.; Hilker, C.; Deuster, S.; Herrmann, R.; Rochlitz, C. Tol-erability, safety, pharmacokinetics, and efficacy of doxorubicin-loaded anti-EGFR immunoliposomes in advanced solid tu-mours: A phase 1 dose-escalation study. Lancet. Oncol. 2012, 13, 1234-1241. [CrossRef]

106. Cai, W.-Q.; Zeng, L.-S.; Wang, L.-F.; Wang, Y.-Y.; Cheng, J.-T.; Zhang, Y.; Han, Z.-W.; Zhou, Y.; Huang, S.-L.; Wang, X.-W.; et al. The Latest Battles Between EGFR Monoclonal Antibodies and Resistant Tumor Cells. Front. Oncol. 2020, 10, 1249. [CrossRef]

107. Santos, E.D.S.; Nogueira, K.A.B.; Fernandes, L.C.C.; Martins, J.R.P.; Reis, A.V.F.; Neto, J.D.B.V.; Júnior, I.J.D.S.; Pessoa, C.; Petrilli, R.; Eloy, J.O. EGFR targeting for cancer therapy: Pharmacology and immunoconjugates with drugs and nanoparticles. Int. J. Pharm. 2020, 592, 120082. [CrossRef]

108. Vergote, I.B.; Jimeno, A.; Joly, F.; Katsaros, D.; Coens, C.; Despierre, E.; Marth, C.; Hall, M.; Steer, C.B.; Colombo, N.; et al. Randomized phase III study of erlotinib versus observation in patients with no evidence of disease progression after firstline platin-based chemotherapy for ovarian carcinoma: A European Organisation for Research and Treatment of Can-cerGynaecological Cancer Group, and Gynecologic Cancer Intergroup study. J. Clin. Oncol 2014, 32, 320-326.

109. Mak, V.C.; Li, X.; Rao, L.; Zhou, Y.; Tsao, S.W.; Cheung, L.W. p85beta alters response to EGFR inhibitor in ovarian cancer through p38 MAPK-mediated regulation of DNA repair. Neoplasia 2021, 23, 718-730. [CrossRef]

110. Stebbins, E.; Russo, A.A.; Schneider, C.; Rosen, N.; Hartl, F.; Pavletich, N.P. Crystal Structure of an Hsp90-Geldanamycin Complex: Targeting of a Protein Chaperone by an Antitumor Agent. Cell 1997, 89, 239-250. [CrossRef]

111. Garcia-Morales, P.; Carrasco-Garcia, E.; Ruiz-Rico, P.; Martinez-Mira, R.; Menendez-Gutierrez, M.P.; Ferragut, J.A.; Saceda, M.; Martinez-Lacaci, I. Inhibition of Hsp90 function by ansamycins causes downregulation of cdc2 and cdc25c and G(2)/M arrest in glioblastoma cell lines. Oncogene 2007, 26, 7185-7193. [CrossRef]

112. Schulte, T.W.; Neckers, L.M. The benzoquinone ansamycin 17-allylamino-17-demethoxygeldanamycin binds to HSP90 and shares important biologic activities with geldanamycin. Cancer Chemother. Pharmacol. 1998, 42, 273-279. [CrossRef] [PubMed]

113. Munster, P.N.; Marchion, D.C.; Basso, A.D.; Rosen, N. Degradation of HER2 by ansamycins induces growth arrest and apop-tosis in cells with HER2 overexpression via a HER3, phosphatidylinositol 3'-kinase-AKT-dependent pathway. Cancer Res. 2002, 62, 3132-3137. [PubMed] 
114. Basso, A.D.; Solit, D.B.; Chiosis, G.; Giri, B.; Tsichlis, P.; Rosen, N. Akt Forms an Intracellular Complex with Heat Shock Protein 90 (Hsp90) and Cdc37 and Is Destabilized by Inhibitors of Hsp90 Function. J. Biol. Chem. 2002, 277, 39858-39866. [CrossRef] [PubMed]

115. Sato, S.; Fujita, N.; Tsuruo, T. Modulation of Akt kinase activity by binding to Hsp90. Proc. Natl. Acad. Sci. USA 2000, 97, 10832-10837. [CrossRef] [PubMed]

116. Choi, Y.E.; Battelli, C.; Watson, J.; Liu, J.; Curtis, J.; Morse, A.N.; Matulonis, U.A.; Chowdhury, D.; Konstantinopoulos, P.A. Sub-lethal concentrations of 17-AAG suppress homologous recombination DNA repair and enhance sensitivity to carboplatin and olaparib in HR proficient ovarian cancer cells. Oncotarget 2014, 5, 2678-2687. [CrossRef]

117. Palombella, V.J.; Rando, O.J.; Goldberg, A.L.; Maniatis, T. The ubiquitin-proteasome pathway is required for processing the NF-kappa B1 precursor protein and the activation of NF-kappa B. Cell 1994, 78, 773-785. [CrossRef]

118. Langer, C.J.; O’Byrne, K.J.; Socinski, M.A.; Mikhailov, S.M.; Lesniewski-Kmak, K.; Smakal, M.; Ciuleanu, T.E.; Orlov, S.V.; Dediu, M.; Heigener, D.; et al. Phase III trial comparing paclitaxel poliglumex (CT-2103, PPX) in combination with carboplatin versus standard paclitaxel and carboplatin in the treatment of PS 2 patients with chemotherapy-naive advanced non-small cell lung cancer. J. Thorac. Oncol. 2008, 3, 623-630. [CrossRef]

119. Vermunt, M.A.; Bergman, A.M.; van der Putten, E.; Beijnen, J.H. The intravenous to oral switch of taxanes: Strategies and current clinical developments. Futur. Oncol. 2021, 17, 1379-1399. [CrossRef]

120. Scholler, N.; Urban, N. CA125 in ovarian cancer. Biomark. Med. 2007, 1, 513-523. [CrossRef]

121. Funston, G.; Hamilton, W.; Abel, G.; Crosbie, E.J.; Rous, B.; Walter, F.M. The diagnostic performance of CA125 for the detection of ovarian and non-ovarian cancer in primary care: A population-based cohort study. PLoS Med. 2020, 17, e1003295. [CrossRef] [PubMed]

122. Yin, B.W.; Dnistrian, A.; Lloyd, K.O. Ovarian cancer antigen CA125 is encoded by theMUC16 mucin gene. Int. J. Cancer 2002, 98 , 737-740. [CrossRef] [PubMed]

123. Frietze, K.M.; Roden, R.B.; Lee, J.-H.; Shi, Y.; Peabody, D.S.; Chackerian, B. Identification of Anti-CA125 Antibody Responses in Ovarian Cancer Patients by a Novel Deep Sequence-Coupled Biopanning Platform. Cancer Immunol. Res. 2015, 4, 157-164. [CrossRef] [PubMed]

124. Wagner, U.; Köhler, S.; Reinartz, S.; Giffels, P.; Huober, J.; Renke, K.; Schlebusch, H.; Biersack, H.J.; Möbus, V.; Kreienberg, R.; et al. Immunological consolidation of ovarian carcinoma recurrences with monoclonal anti-idiotype antibody ACA125: Immune responses and survival in palliative treatment. See The biology behind: K. A. Foon and M. Bhattacharya-Chatterjee, Are solid tumor anti-idiotype vaccines ready for prime time? Clin. Cancer Res. 2001, 7, 1112-1115.

125. Palaia, I.; Tomao, F.; Sassu, C.M.; Musacchio, L.; Panici, P.B. Immunotherapy For Ovarian Cancer: Recent Advances And Combination Therapeutic Approaches. OncoTargets Ther. 2020, 13, 6109-6129. [CrossRef] [PubMed]

126. Raave, R.; de Vries, R.B.; Massuger, L.F.; van Kuppevelt, T.H.; Daamen, W.F. Drug delivery systems for ovarian cancer treat-ment: A systematic review and meta-analysis of animal studies. PeerJ. 2015, 3, e1489. [CrossRef]

127. Zeng, Q.; Saha, S.; Lee, L.A.; Barnhill, H.; Oxsher, J.; Dreher, T.; Wang, Q. Chemoselective modification of turnip yellow mosaic virus by $\mathrm{Cu}(\mathrm{I})$ catalyzed azide-alkyne 1,3-dipolar cycloaddition reaction and its application in cell binding. Bioconjug. Chem. 2011, 22, 58-66. [CrossRef]

128. Ye, H.; Karim, A.A.; Loh, X.J. Current treatment options and drug delivery systems as potential therapeutic agents for ovarian cancer: A review. Mater. Sci. Eng. C 2014, 45, 609-619. [CrossRef]

129. Manchester, M.; Singh, P. Virus-based nanoparticles (VNPs): Platform technologies for diagnostic imaging. Adv. Drug Deliv. Rev. 2006, 58, 1505-1522. [CrossRef]

130. Levit, S.; Tang, C. Polymeric Nanoparticle Delivery of Combination Therapy with Synergistic Effects in Ovarian Cancer. Nanomaterials 2021, 11, 1048. [CrossRef]

131. Kumar, A.; Bhattacharya, S.; Sharma, V.; Singh, C. Poly (Lactic-co-Glycolic Acid) \& Tocopheryl Polyethylene Glycol Succinate Nanoparticles for the Treatment of Different Brain Cancers. Anti-Cancer Agents Med. Chem. 2021, 21, 1977-1986. [CrossRef]

132. Cheng, Z.; Li, M.; Dey, R.; Chen, Y. Nanomaterials for cancer therapy: Current progress and perspectives. J. Hematol. Oncol. 2021, 14, 1-27. [CrossRef] [PubMed]

133. Rother, M.; Nussbaumer, M.G.; Renggli, K.; Bruns, N. Protein cages and synthetic polymers: A fruitful symbiosis for drug delivery applications, bionanotechnology and materials science. Chem. Soc. Rev. 2016, 45, 6213-6249. [CrossRef] [PubMed]

134. Holditch, S.J.; Brown, C.N.; Lombardi, A.M.; Nguyen, K.N.; Edelstein, C.L. Recent Advances in Models, Mechanisms, Biomarkers, and Interventions in Cisplatin-Induced Acute Kidney Injury. Int. J. Mol. Sci. 2019, 20, 3011. [CrossRef]

135. Paraskar, A.S.; Soni, S.; Chin, K.T.; Chaudhuri, P.; Muto, K.W.; Berkowitz, J.; Handlogten, M.W.; Alves, N.J.; Bilgicer, B.; Dinulescu, D.M.; et al. Harnessing structure-activity relationship to engineer a cisplatin nanoparticle for enhanced antitumor efficacy. Proc. Natl. Acad. Sci. USA 2010, 107, 12435-12440. [CrossRef] [PubMed]

136. Tan, J.; Cho, T.J.; Tsai, D.H.; Liu, J.; Pettibone, J.M.; You, R.; Hackley, V.A.; Zachariah, M.R. Surface Modification of Cispla-tinComplexed Gold Nanoparticles and Its Influence on Colloidal Stability, Drug Loading, and Drug Release. Langmuir 2018, 34, 154-163. [CrossRef]

137. Gelderblom, H.; Verweij, J.; Nooter, K.; Sparreboom, A. Cremophor EL: The drawbacks and advantages of vehicle selection for drug formulation. Eur. J. Cancer 2001, 37, 1590-1598. [CrossRef] 
138. Yuan, D.-M.; Lv, Y.-L.; Yao, Y.-W.; Miao, X.-H.; Wang, Q.; Xiao, X.-W.; Yin, J.; Shi, Y.; Shi, M.-Q.; Zhang, X.-W.; et al. Efficacy and safety of Abraxane in treatment of progressive and recurrent non-small cell lung cancer patients: A retrospective clinical study. Thorac. Cancer 2012, 3, 341-347. [CrossRef]

139. Kundranda, M.N.; Niu, J. Albumin-bound paclitaxel in solid tumors: Clinical development and future directions. Drug Des. Dev. Ther. 2015, 9, 3767-3777. [CrossRef] [PubMed]

140. Feng, Z.; Zhao, G.; Yu, L.; Gough, D.; Howell, S.B. Preclinical efficacy studies of a novel nanoparticle-based formulation of paclitaxel that out-performs Abraxane. Cancer Chemother. Pharmacol. 2009, 65, 923-930. [CrossRef] [PubMed]

141. Zeng, Q.; Wen, H.; Wen, Q.; Chen, X.; Wang, Y.; Xuan, W.; Liang, J.; Wan, S. Cucumber mosaic virus as drug delivery vehicle for doxorubicin. Biomaterials 2013, 34, 4632-4642. [CrossRef] [PubMed]

142. Qi, S.-S.; Sun, J.-H.; Yu, H.-H.; Yu, S.-Q. Co-delivery nanoparticles of anti-cancer drugs for improving chemotherapy efficacy. Drug Deliv. 2017, 24, 1909-1926. [CrossRef] [PubMed]

143. Khan, I.U.; Khan, R.U.; Asif, H.; Alamgeer; Khalid, S.H.; Asghar, S.; Saleem, M.; Shah, K.U.; Shah, S.U.; Rizvi, S.A.A.; et al Co-delivery strategies to overcome multidrug resistance in ovarian cancer. Int. J. Pharm. 2017, 533, 111-124. [CrossRef]

144. Devalapally, H.; Duan, Z.; Seiden, M.V.; Amiji, M.M. Paclitaxel and ceramide co-administration in biodegradable polymeric nanoparticulate delivery system to overcome drug resistance in ovarian cancer. Int. J. Cancer 2007, 121, 1830-1838. [CrossRef] [PubMed]

145. Sheikh, A.; Md, S.; Kesharwani, P. RGD engineered dendrimer nanotherapeutic as an emerging targeted approach in cancer therapy. J. Control. Release 2021, 340, 221-242. [CrossRef]

146. Shah, V.; Taratula, O.; Garbuzenko, O.B.; Taratula, O.R.; Rodriguez-Rodriguez, L.; Minko, T. Targeted nanomedicine for suppression of CD44 and simultaneous cell death induction in ovarian cancer: An optimal delivery of siRNA and anticancer drug. Clin. Cancer Res. 2013, 19, 6193-6204. [CrossRef]

147. Bholakant, R.; Qian, H.; Zhang, J.; Huang, X.; Huang, D.; Feijen, J.; Zhong, Y.; Chen, W. Recent Advances of Polycationic siRNA Vectors for Cancer Therapy. Biomacromolecules 2020, 21, 2966-2982. [CrossRef]

148. Senapati, S.; Mahanta, A.K.; Kumar, S.; Maiti, P. Controlled drug delivery vehicles for cancer treatment and their performance. Signal Transduct. Target. Ther. 2018, 3, 7. [CrossRef]

149. Menon, U.; Gentry-Maharaj, A.; Burnell, M.; Singh, N.; Ryan, A.; Karpinskyj, C.; Carlino, G.; Taylor, J.; Massingham, S.K.; Raikou, M.; et al. Ovarian cancer popu-lation screening and mortality after long-term follow-up in the UK Collaborative Trial of Ovarian Cancer Screening (UKCTOCS): A randomised controlled trial. Lancet 2021, 397, 2182-2193. [CrossRef]

150. Matulonis, U.A.; Sood, A.K.; Fallowfield, L.; Howitt, B.E.; Sehouli, J.; Karlan, B.Y. Ovarian cancer. Nat. Rev. Dis. Primers 2016, 2, 16061. [CrossRef]

151. Chandra, A.; Pius, C.; Nabeel, M.; Nair, M.; Vishwanatha, J.K.; Ahmad, S.; Basha, R. Ovarian cancer: Current status and strat-egies for improving therapeutic outcomes. Cancer Med. 2019, 8, 7018-7031. [CrossRef]

152. Luvero, D.; Milani, A.; Ledermann, J.A. Treatment options in recurrent ovarian cancer: Latest evidence and clinical potential. Ther. Adv. Med. Oncol. 2014, 6, 229-239. [CrossRef]

153. Sazonova, E.V.; Kopeina, G.S.; Imyanitov, E.N.; Zhivotovsky, B. Platinum drugs and taxanes: Can we overcome resistance? Cell Death Discov. 2021, 7, 155. [CrossRef] [PubMed]

154. Bukowski, K.; Kciuk, M.; Kontek, R. Mechanisms of Multidrug Resistance in Cancer Chemotherapy. Int. J. Mol. Sci. 2020, $21,3233$. [CrossRef]

155. Pokhriyal, R.; Hariprasad, R.; Kumar, L.; Hariprasad, G. Chemotherapy Resistance in Advanced Ovarian Cancer Patients. Biomark. Cancer 2019, 11, 1179299X19860815. [CrossRef]

156. Cho, Y.; Kim, Y.K. Cancer Stem Cells as a Potential Target to Overcome Multidrug Resistance. Front. Oncol. $2020,10,764$. [CrossRef] [PubMed]

157. Liu, Y.; Zheng, C.; Huang, Y.; He, M.; Xu, W.W.; Li, B. Molecular mechanisms of chemo- and radiotherapy resistance and the potential implications for cancer treatment. MedComm. 2021, 2, 315-340. [CrossRef]

158. Li, X.; Chen, W.; Zeng, W.; Wan, C.; Duan, S.; Jiang, S. microRNA-137 promotes apoptosis in ovarian cancer cells via the regu-lation of XIAP. Br. J. Cancer 2017, 116, 66-76. [CrossRef] [PubMed]

159. Yang, W.; Mu, T.; Jiang, J.; Sun, Q.; Hou, X.; Sun, Y.; Zhong, L.; Wang, C.; Sun, C. Identification of Potential Biomarkers and Metabolic Profiling of Serum in Ovarian Cancer Patients Using UPLC/Q-TOF MS. Cell. Physiol. Biochem. 2018, 51, 1134-1148. [CrossRef] [PubMed]

160. Akter, S.; Choi, T.G.; Nguyen, M.N.; Matondo, A.; Kim, J.-H.; Jo, Y.H.; Jo, A.; Shahid, M.; Jun, D.Y.; Yoo, J.Y.; et al. Prognostic value of a 92-probe signature in breast cancer. Oncotarget 2015, 6, 15662-15680. [CrossRef]

161. Soto, J.A.; Rodriguez-Antolin, C.; Vera, O.; Pernia, O.; Esteban-Rodriguez, I.; Dolores Diestro, M.; Benitez, J.; Sanchez-Cabo, F.; Alvarez, R.; De Castro, J.; et al. Transcriptional epigenetic regulation of Fkbp1/Pax9 genes is associated with impaired sensitivity to platinum treatment in ovarian cancer. Clin. Epigenet. 2021, 13, 167. [CrossRef] [PubMed]

162. Häfner, N.; Steinbach, D.; Jansen, L.; Diebolder, H.; Dürst, M.; Runnebaum, I.B. RUNX3 and CAMK2N1 hypermethylation as prognostic marker for epithelial ovarian cancer. Int. J. Cancer 2016, 138, 217-228. [CrossRef]

163. Tassi, R.A.; Todeschini, P.; Siegel, E.R.; Calza, S.; Cappella, P.; Ardighieri, L.; Cadei, M.; Bugatti, M.; Romani, C.; Bandiera, E.; et al. FOXM1 expression is significantly as-sociated with chemotherapy resistance and adverse prognosis in non-serous epithelial ovarian cancer patients. J. Exp. Clin. Cancer Res. 2017, 36, 63. [CrossRef] [PubMed] 
164. Gonzalez-Martin, A.; Pothuri, B.; Vergote, I.; DePont Christensen, R.; Graybill, W.; Mirza, M.R.; McCormick, C.; Lorusso, D.; Hoskins, P.; Freyer, G.; et al. Niraparib in Patients with Newly Diagnosed Ad-vanced Ovarian Cancer. N. Engl. J. Med. 2019, 381, 2391-2402. [CrossRef]

165. Oza, A.M.; Matulonis, U.A.; Malander, S.; Hudgens, S.; Sehouli, J.; Del Campo, J.M.; Berton-Rigaud, D.; Banerjee, S.; Scambia, G.; Berek, J.S. er al. Quality of life in patients with recurrent ovarian cancer treated with niraparib versus placebo (EN-GOTOV16/NOVA): Results from a double-blind, phase 3, randomised controlled trial. Lancet Oncol. 2018, 19, 1117-1125. [CrossRef]

166. Longo, D.L. Personalized Medicine for Primary Treatment of Serous Ovarian Cancer. N. Engl. J. Med. 2019, 381, 2471-2474. [CrossRef]

167. Yeh, C.-M.; Shay, J.; Zeng, T.-C.; Chou, J.-L.; Huang, T.H.-M.; Lai, H.-C.; Chan, M. Epigenetic silencing of ARNTL, a circadian gene and potential tumor suppressor in ovarian cancer. Int. J. Oncol. 2014, 45, 2101-2107. [CrossRef]

168. Chen, M.; Zhang, L.; Liu, X.; Ma, Z.; Lv, L. PER1 Is a Prognostic Biomarker and Correlated With Immune Infiltrates in Ovarian Cancer. Front. Genet. 2021, 12, 984. [CrossRef]

169. Heinze, K.; Rengsberger, M.; Gajda, M.; Jansen, L.; Osmers, L.; Oliveira-Ferrer, L.; Schmalfeldt, B.; Durst, M.; Hafner, N.; Runnebaum, I.B. CAMK2N1/RUNX3 methylation is an independent prognostic biomarker for progression-free and overall survival of platinum-sensitive epithelial ovarian cancer patients. Clin. Epigenet. 2021, 13, 15. [CrossRef]

170. Wu, Y.-H.; Chang, T.-H.; Huang, Y.-F.; Huang, H.-D.; Chou, C.-Y. COL11A1 promotes tumor progression and predicts poor clinical outcome in ovarian cancer. Oncogene 2013, 33, 3432-3440. [CrossRef]

171. Zhang, S.; Cheng, J.; Quan, C.; Wen, H.; Feng, Z.; Hu, Q.; Zhu, J.; Huang, Y.; Wu, X. circCELSR1 (hsa_circ_0063809) Contributes to Paclitaxel Resistance of Ovarian Cancer Cells by Regulating FOXR2 Expression via miR-1252. Mol. Ther. Nucleic Acids 2020, 19, 718-730. [CrossRef]

172. Lee, J.; Kim, S.; Oh, Y.; Kim, J.; Lee, S.; Chae, H. Increased Expression of Retinol-Binding Protein 4 in Ovarian Endometrioma and Its Possible Role in the Pathogenesis of Endometriosis. Int. J. Mol. Sci. 2021, 22, 5827. [CrossRef] [PubMed]

173. Avril, S.; Dincer, Y.; Malinowsky, K.; Wolff, C.; Gündisch, S.; Hapfelmeier, A.; Boxberg, M.; Bronger, H.; Becker, K.-F.; Schmalfeldt, B. Increased PDGFR-beta and VEGFR-2 protein levels are associated with resistance to platinum-based chemotherapy and adverse outcome of ovarian cancer patients. Oncotarget 2017, 8, 97851-97861. [CrossRef] [PubMed]

174. Mukherjee, S.; Sundfeldt, K.; Borrebaeck, C.; Jakobsson, M. Comprehending the Proteomic Landscape of Ovarian Cancer: A Road to the Discovery of Disease Biomarkers. Proteomes 2021, 9, 25. [CrossRef] [PubMed]

175. Natanzon, Y.; Goode, E.L.; Cunningham, J.M. Epigenetics in ovarian cancer. Semin. Cancer Biol. 2017, 51, 160-169. [CrossRef] 